\title{
Estimating Wage Losses of Displaced Workers in Germany
}

\author{
Michael Burda \\ Humboldt-Universität zu Berlin \\ and CEPR
}

\author{
Antje Mertens \\ Max Planck Institute (MPIB) and \\ Humboldt-Universität zu Berlin
}

January 1999

\begin{abstract}
This paper investigates the effect of displacement on reemployment wages of socially insured West German workers who became unemployed in 1986. Because detailed information on the cause of job loss is unavailable, displacement status is imputed using a probit estimated on the German Socioeconomic Panel (GSOEP). Average wages of those classified as displaced decline only slightly upon reemployment. The lowest earnings quartile, in which displacement is concentrated, even gains slightly $(+2 \%)$, while wage growth losses for the upper three quartiles are comparable to US findings $(-17 \%)$. Large wage losses are associated with changes of industry, but not of firm. Our results are robust to controls for heterogeneity, for recalls, and to the probit specification used, and are confirmed in the smaller GSOEP file.
\end{abstract}

\section{Keywords: displaced workers, wages, tenure, wage rigidity JEL Numbers: J30, J63, J65}

\footnotetext{
We are grateful to Stefan Bender for help with the IAB data set and Alison Booth, Christian Dustmann, Heinz Galler, Dan Hamermesh, Geneviève Knight, Michael Lechner, Christopher Ruhm, Christoph Schmidt, Stefan Sperlich, and participants at the December 1997 LoWer Conference (London), the 1998 meeting of the Bevölkerungsausschuss (Freiburg), the LSE Wages and Job Tenure Conference (April 1998), the German Labor Markets 1998 Berlin Conference and the EEA98 for comments on an earlier version of this paper. This work was supported by the German Science Foundation, Sonderforschungsbereich 373 "Quantification and Simulation of Economic Processes." Address: Faculty of Economics, Humboldt-University Berlin, Spandauer Strasse 1, D-10178 Germany or Max Planck Institute for Human Development, Lentzeallee 94, D-14195 Berlin. Homepage: http://www.wiwi.hu-berlin.de/wt2/; email: burda@wiwi.hu-berlin.de, mertens@ mipb-berlin.mpg.de.
} 


\section{Introduction}

A great deal of attention has been paid in recent years to the consequences of worker displacement for individual labor market outcomes. Displacement is usually defined as the separation of workers from their jobs "without cause" (i.e. for economic reasons) and without future recall. This type of involuntary rupture in employment relationships is generally attributed to structural change, sectoral reallocation or technological innovation. In the United States, displacement is statistically associated with severe and lasting earnings "losses" on the order of $10 \%-25 \%$.

Studying the consequences of worker displacement is important for at least three reasons. First, it is important to know whether displacement is a serious problem that policymakers should care about. Second, consequences of worker displacement can help discriminate among theories of wage determination. Human capital theory relates wage losses to specificity of previous skills and training; search and matching theory predicts instead that employees with long tenure receive high wages because high productivity matches tend to last longer; contract theories imply that young displaced workers should suffer smaller wage losses than more seasoned colleagues, whose pay tends to exceed productivity. Third, macroeconomic theory can be informed by the effects of job displacement on wages and employment. To the extent that persistent deviations of output from trend are related to nominal and real wage rigidities, job displacement could represent a mechanism of macroeconomic adjustment comparable to nominal wage reductions or unanticipated price level increases. For example, conventional wisdom holds that real wages are rigid in Europe and flexible in the United States. Although it is often asserted that post-displacement wage behavior in Europe is different than in the United States, the hypothesis has rarely been investigated at the microeconomic level. ${ }^{1}$ The absence of a conclusive literature on displacement and wages in Europe is largely due to a lack of suitable data. In particular, it is rarely possible to identify workers explicitly as displaced.

This paper attempts to close this gap. Using a newly available $1 \%$ public use panel sample of the universe of dependent status employed workers, we investigate the effect of displacement on reemployment wages in Germany, the largest economy of the European Union. Despite its size and extensive coverage, our dataset has one significant drawback: it does not contain direct information on reason for separation. To circumvent this problem, we

\footnotetext{
1 See Sachs (1979, 1983), Branson and Rotemberg (1980), and Bruno and Sachs (1985), for the original references on the implications of aggregate wage rigidity. In a similar spirit, Ljungqvist and Sargent (1998) have recently related high European unemployment to the social safety net via its effect on the flexibility of reservation wages, although they only cite evidence from the United States to document their point.
} 
impute displacement status using information from a smaller, independent, and richer data source, the German Socioeconomic Panel (GSOEP), which includes self-reported information on the reason for unemployment. Put another way, we use the GSOEP data to estimate a probit model of job displacement, and then define displacement in the IAB sample as those workers with a sufficiently high probit value. On the basis of this classfication, we compare post-reemployment wages of such workers with those who did not experience unemployment or entered unemployment for other reasons. Using a variety of alternative estimation procedures - including verification using the GSOEP data -- we attempt to bound potential effects of misclassification.

Overall, our results point to striking differences in German post-displacement wage behavior compared with the United States. Our most important finding is that displacement for the average German worker is not associated with economically significant loss of wage growth. Full-time men displaced in 1986 and subsequently re-employed in 1987 suffer a reduction of wage growth of only $3.6 \%$ when compared with a reference group of continuously employed workers. At the same time, post-displacement wage behavior varies significantly across previous position in the wage distribution. Displaced workers in the upper three quartiles experience $17 \%$ lower average wage growth than comparable non-displaced workers, while wage growth in the lowest quartile is slightly higher than that of other low wage workers. Patterns of industrial and occupational mobility in the face of displacement are consistent with losses of industry-specific human capital: the mobility rate of displaced workers is roughly 35\% between 1986 and 1987, compared with average mobility rates for nondisplaced full-time workers of only 5\%. Consistent with Neal's (1995) findings for the US, firm tenure and wages are primarily but not wholly driven by industry-specific factors.

The rest of the paper is organized as follows: Section 2 gives a brief review of the literature on worker displacement. Section 3 describes the data and gives details on the estimation and classification procedures. Section 4 presents the basic estimates of the effects of displacement on wage growth, while Section 5 assesses the robustness of our results in several directions. In Section 6, the analysis is extended and results are presented on the persistence of wage losses and the relationship between wage growth, industrial mobility and industry tenure. Finally, Section 7 concludes. 


\section{Worker Displacement: A Literature Review}

Research on the effects of worker displacement in the United States has grown dramatically in recent years (see Hamermesh, 1989; Farber, 1993 and 1997; Hall, 1995; Fallick, 1996 and Kletzer, 1998 for surveys). Using a variety of methods and datasets, the findings are remarkably consistent. First, displaced workers in the US face large and persistent earnings losses upon reemployment (Podgursky and Swaim, 1987; Hamermesh, 1987; Addison and Portugal, 1989; Kletzer, 1989, 1991 and 1996; Carrington, 1993; Farber, 1993; Jacobsen et al., 1993). Point estimates of wage loss in these studies range from $10 \%$ to $25 \%$. Ruhm (1987) reports declines in wage growth of 13.6\%; Bartel and Borjas (1981) estimate losses of around $10 \%$ for older men. Workers with seniority are less likely to experience displacement, but if displaced their wage losses are greater (Farber 1993), hinting at a nexus with job tenure. ${ }^{2}$ Overall, individual characteristics play a smaller role than industry conditions and other economy-wide factors (Jacobsen et al., 1993). Carrington (1993) argues that much of the wage losses of high tenure workers are attributable to downturns in their industry, state or occupation.

Second, in addition to earnings losses, displaced workers in the United States experience more unemployment than non-displaced workers (Swaim and Podgursky, 1991 and Ruhm, 1991). Hall (1995) links displacement to a period of slow rebuilding of employment relationships, as workers displaced from long-term jobs require time to find acceptable matches. Ruhm (1991) shows for the United States that displaced workers face eight weeks more unemployment than comparable workers in the year of displacement, only four more weeks the following year and only six days four years later.

In contrast to the impressive consensus on worker displacement in the United States and Canada, evidence for European labor markets is scant and not always comparable. Leonard and Audenrode (1995) examine the consequences of job loss for a large sample of Belgian workers and find that wage losses upon re-employment are near zero. Similarly, Ackum (1991) finds no significant earnings loss in Sweden. Pichelmann and Riedel (1993) report wage losses for Austria in the short term only. In Germany, there is little if any comparable work on post-reemployment wages of displaced workers. One related study is

\footnotetext{
2 Although an immediate interpretation of the US evidence is the destruction of firm-specific human capital associated with tenure, non-observed individual heterogeneity may bias estimated returns to tenure upwards, so that previous tenure might have a positive effect on post-displacement wage rates (see Kletzer (1989) for evidence for the U.S). Another interpretation is simply the destruction of rents associated with good matches, with no returns to tenure per se, as has been argued by Mincer and Jovanovic (1981), Altonji and Shakotko (1987), Abraham and Farber (1987), followed by Ruhm (1990) and Altonji and Williams (1992). In contrast, Topel (1991) and Topel and Ward (1992) find substantial returns to seniority. Recently Dustmann and Meghir
} 
Buttler and Bellmann (1991) who define displaced workers as having left a job in an industry with employment declines of $30 \%$ or more between 1974 and 1986 . They identify wage losses primarily for elder and unskilled workers. Gerlach and Schasse (1990) use the GSOEP to show that displaced workers are more likely to experience subsequent unemployment than quitters and are less capable of transferring human capital across firms.

In both the US and Europe, emphasis in displacement research has shifted from shortterm wage losses to longer-term wage evolution before and after displacement. Ruhm (1991, 1987) estimates wage growth regressions for several years following displacement and identifies wage losses of $10-13 \%$ even four years after the displacement in comparison with non-displaced workers. Jacobsen et al. (1993) adduce impressive evidence that wages start to fall approximately four years prior to the displacement, reach a trough at the time of displacement and rise slowly again afterwards. In contrast, Hamermesh (1987) finds that wage-tenure-profiles do not flatten as job loss approaches, suggesting that events may take workers and firms by surprise. Gregory and Jukes (1997) estimate pooled wage level regressions with dummy variables indicating the end (commencement) of the most recent unemployment spell " $\mathrm{x}$ " quarters before (after) the wage observation, and find that future unemployment is negatively correlated with current earnings. Leonard and Audenrode (1995) estimate a significant coefficient on future job loss in wage level equations on data prior to displacement. Similar results are presented by Ruhm (1990) for the United States.

\section{Identifying Displaced Workers in German Data Sets}

Even assuming that agreement is possible on a definition of displacement - for example, hightenured workers fired for structural reasons relating to the firm or industry - it is generally only possible to identify displaced worker directly using self-reported information. Researchers without access to information on reason for job termination often infer displacement from previous industry, tenure or employment reductions within an industry or firm (see Buttler and Bellmann, 1991; Jacobsen et al., 1993; Leonard and Audenrode, 1995; Mertens, 1997 and 1998; Dustmann et al. 1998). Precisely for this reason, the literature on worker displacement in Germany is rather limited. In the two data sets used in this study, either the number of observations is modest (in the German Socioeconomic Panel, hereafter GSOEP) or reasons for separations are unknown (the IAB social security file). The idea in this paper is to estimate a probit model for displacement using the more detailed information available in the GSOEP and use the probit scores to predict involuntary separation in the IAB 
sample. We therefore define displacement as possessing a vector of attributes which are sufficiently similar to displaced individuals in the representative GSOEP dataset. ${ }^{3}$

To achieve approximate correspondence in the two data sets, a number of restrictions were imposed on the GSOEP data used in estimation. East Germans were omitted for reasons not only related to the peculiarites of German reunification, but more importantly to their current absence from the IAB sample. Only full-time workers were considered, because the IAB data does not include detailed information on hours worked. Workers who were civil servants or gave up their own businesses were also dropped, since these workers are not included in the IAB sample. Given the high level of subsidies and "informal employment" in agriculture, forestry and fisheries, these sectors were excluded, as were individuals working for non-profit organizations. Workers who just completed an apprenticeship were also excluded. Most importantly, in the primary analysis we restrict attention to workers who experienced some unemployment after separation from their old job. ${ }^{4}$ Table 1 shows that this restriction is sensible: $46 \%$ of all employees who report to have changed their job and experienced some unemployment say that this was due to having been made redundant, compared with only $8.8 \%$ of employees who experienced no intervening unemployment. Later in Section 5.2., this restriction will be relaxed and the analysis repeated using all job movers. Somewhat surprisingly, $22.9 \%$ of the GSOEP sample report quitting as the cause of unemployment. This seems somewhat high compared with available data from the United States and the United Kingdom; for example, in the US in 1996 and 1997, 10.7 and $11.8 \%$ left their jobs into unemployment, respectively (Employment and Earnings 1998). In contrast, the overall German quit rate of $39.5 \%$ for all workers with some change in their job (including quits into unemployment) is comparable to these countries.

\section{< Table 1 around here>}

We estimate pooled probit equations predicting involuntary separations among unemployed workers. The dependent variable equals one if the worker reports to have been laid off, zero otherwise. The most serious problem with this definition of displacement is that workers fired for cause will be included, yet sample information is not available that would allow us to distinguish these cases. Our choice of explanatory variables follows Blau and

\footnotetext{
${ }^{3}$ See the Appendix for information on the data sets and data selection problems.

${ }^{4}$ We define workers as unemployed if 1) they experienced some unemployment after their last employment spell or 2) they were unemployed at the interview date. A calendar in the GSOEP gives this information on a monthly basis.
} 
Kahn (1981). Table 2 displays several specifications. The first two columns include individual characteristics and previous job tenure as explanatory variables. Displacement is more likely to have caused unemployment for older workers than for young ones, who often quit into unemployment. Foreigners are significantly more likely to be displaced than German nationals, while workers with technical training or university education are less likely to be laid off. Interaction terms between age and education show that older workers with technical training are displaced more often and older university graduates less often. As a rule, white collar workers are laid off less frequently than are blue collar workers. Job tenure is entered as two dummy variables for tenure up to three years and tenure between three and ten years, so the control group has ten or more years of tenure. Although the sign on the dummy variables is positive as expected (less tenure increases the probability of displacement), these coefficients are not statistically significant.

The predictive power of these two models can be improved by adding firm size, sectoral (industry) and time dummy variables for year of displacement (1984-1993). Workers in small firms are displaced more frequently than in medium-sized ones, although the coefficients are only marginally significant at conventional significance levels. The highest displacement rates are found in construction and the transport/communications sector followed by other services, manufacturing and trade. Compared with the reference year 1993, significantly lower displacement rates are found in the years immediately following German reunification (1990-1992). Our results largely corroborate those reported by Blau and Kahn (1981), in which age, tenure, industry and business cycle (i.e. calendar time) effects all are significantly associated with displacement. Adding industry employment growth hardly changes the results, so the probit from specification IV will be used to predict displacement status on the sample of all workers in the IAB sample who became unemployed in a single year, 1986.5 An observation is predicted as displaced if the estimated probability is equal to or greater than 0.46 (the fraction of displacements in the sample) and not displaced otherwise.

\section{$<$ Table 2 around here $>$}

\footnotetext{
${ }^{5}$ In addition to the specifications discussed, we also included female and occupation dummies, but these did not significantly influence the results and were omitted.
} 


\section{Displacement and Wage Growth in Cross Tabulations and Wage Regressions}

\subsection{Displacement Incidence}

In this section we assess patterns of incidence of unemployment and the wage effects of involuntary displacement. The analysis focuses on daily wages of full-time workers, as the IAB data set does not contain direct information on hours worked. ${ }^{6}$ Of all 146,116 full-time employees with valid information in the 1986 sample, $6.5 \%$ became unemployed at least once in 1986. For men, the percentage is only slightly higher at $6.8 \%$. Of all full-time workers who became unemployed in 1986, roughly 80\% find either full-or part-time employment by 1990 ( $83 \%$ of all men). Only slightly less, i.e. $78 \%$ are re-employed in full-time work ( $82 \%$ of all men). Figure 1, which displays non-employment survival functions for men and women becoming unemployed in 1986, documents that most new jobs are found within a year.

\section{< Figure 1 about here>}

In the Appendix (Table A1) we report summary statistics on wage growth betweeen 1986 and 1987 in the IAB sample - proxied as log wage differences - for men and women separately, all employees, and workers classified as displaced using our procedure. Average wage growth of workers with unemployment who were not displaced is higher than the average for all employed, and displaced workers fare worse. Women in general and unemployed women in particular show higher wage growth than men in the first two years following separation. Subsequent lines of Table A1 document significant male-female differences: men displaced in 1986 who begin a new full-time job in the same year face wage losses on average, while displaced women usually have higher wage growth compared with men. One potential explanation for this finding is that women are more likely than men to have spouse or partner who can provide financial support for longer search. These striking gender differences in wage behavior motivated us to focus exclusively on males for the remainder of the analysis.

As pointed out above, there are major differences in the incidence of displacement across industries. For workers becoming unemployed in 1986 and reemployed in 1987,

\footnotetext{
${ }^{6}$ Foreigners are also excluded, which turns out to be important, given the statistical significance of the foreigner dummy in the probit estimates. Furthermore, only individuals are included that have valid observations for covariates used in the probit estimation. One unemployment spell per person is analyzed, so subsequent multiple unemployment spells are disregarded in the analysis. Because short-time work is not reported in the IAB sample, workers in firms with structural problems may work shorter hours before they are displaced, reducing the daily wage. Consequently, workers earning less than a minimum plausible income of $33 \mathrm{DM} /$ day (around $12,000 \mathrm{DM} / \mathrm{year})$ were excluded from the sample.
} 
displacement is highest in the construction sector, while no workers were classified displaced in energy and mining, the state sector and credit and insurance. High displacement in construction reflects seasonally-related recalls, while low displacement sectors are recognized as either highly regulated, subsidized, or subject to limited competition. An important and surprising finding is that a significant number of those classified as displaced in Germany are "recalled" in all industries, as is frequently the case in the United States. ${ }^{7}$ With respect to the 1986 sample, $53 \%$ of workers classified as displaced later resume work with their employer prior to the joblessness spell. This finding is not due to our classification procedure, since $46 \%$ of all unemployed workers with a spell in 1986 - irrespective of reason - also return to their previous employer within the subsequent year. ${ }^{8}$ These findings are consistent with those of Mavromaras and Rudolph (1995), who find that on average 12\% of all new employment contracts are recalls in the IAB sample. Despite the existence of short-time working, many firms apparently use recalls as an employment management tool.

\subsection{Wage Growth Regressions}

\section{Specification and Other Econometric Issues}

It is standard practice to compare the wage growth of displaced workers with that of workers in stable employment by means of regression analysis, controlling for observable individual and occupational characteristics. First differences in log wage are regressed on a constant, age, age squared, educational and worker status dummies, as well as other variables including tenure, tenure squared, and occupation dummies. The coefficient on a dummy variable for displacement-classification is included to assess the loss in wage growth of these workers. ${ }^{9}$ In theory, nonlinearity of the probit is sufficient to deliver identification, since the displacement indicator is not simply a linear combination of other regressors. Yet a number of covariates in the probit are also excluded from the wage growth equation. These include the calendar year of displacement (representing primarily cyclical factors), age-training interactions, the foreigner-dummy and industry. ${ }^{10}$ All of these variables were statistically significant predictors of displacement status in the GSOEP, and would seem unlikely candidates for contributing to

\footnotetext{
${ }^{7}$ See Ehrenberg and Smith (1991:583), Filer, et al.(1998: 354). According to the latter authors, nearly one-third of all temporary layoffs in the US are recalled within one month of becoming unemployed.

${ }^{8}$ We potentially underestimate true recalls, since the basis for our calculations is the employer social security identifier, which may change when firms merge, divest themselves of subdivisions, reorganize, or otherwise change identity.

9 See Bartel and Borjas (1981) and Ruhm (1987, 1991) for examples of research which implement this statistical model.

10 The inclusion of industry dummies did not significantly change estimated coefficients on other variables.
} 
the differential dynamics of wages per se (although it is well-established that they are correlated with wage levels).

Because displacement status is an imputed variable, our estimation procedure is inevitably subject to measurement error. Some individuals will be predicted as displaced when not (false positives or Type I error) while others are classified as not displaced when in fact they are (false negatives or Type II error). If the probit is misspecified, the predominance of one form of classification error can induce estimation bias: assuming that workers quit for jobs paying better than the previous ones, Type I error will generally biases wage losses downwards; prevalence of Type II error biases estimated wage losses upwards. One way to get around this problem is simply to include the probit score itself as a regressor instead of the dichotomous displacement state inferred using an arbitrary cutoff point. On the other hand, even if estimated status itself is unbiased, a two step estimation procedure of the type we use leads to underestimated standard errors (Murphy and Topel 1985). We thus present the alternative standard errors in both models using the correction proposed by Murphy and Topel (1985) in those models that include the probit score itself. Finally, in an alternative procedure we instrument the imputed displacement state with the probit value. The results of all three procedures are presented in the following section.

\section{Results}

Table 3 presents the estimated coefficients on the displacement dummies and probit values in the wage growth regressions of male workers between 1986 and 1987. Detailed estimation results, excluding recalls, are presented in the Appendix as Table A2. In these regressions, workers employed 365 days in both years (1986 and 1987) were included as a control group. ${ }^{11}$ Specifications i) and ii) in the first two lines of Table 3 compare the estimated coefficient on the displacement dummy when recalled individuals are included and excluded from the sample. The suspicion that the two samples are fundamentally different is confirmed by estimation results on the two groups; Chow tests consistently rejected homogeneity of the two samples $\left(\mathrm{F}_{(22,75777)}=236.63\right)$. The second line in Table 3 shows that on average displaced workers have $3.4 \%$ lower wage growth than non-displaced workers, excluding recalls. ${ }^{12}$

\section{$<$ Table 3 about here>}

\footnotetext{
11 Very similar estimates are obtained when all other workers who work in both years are also included in the control group.

12 The percentage change can be calculated by using the formula $\left(\mathrm{e}^{\mathrm{d}}-1\right) * 100$, where $\mathrm{d}$ is the parameter estimate on the dummy variable (see Halvorsen and Palmquist, 1980).
} 


\section{$<$ Figure 2 about here $>$}

The imputation of displacement decreases with wage levels, as Figure 2 shows. It seemed sensible to estimate separate regressions for male workers in each quartile of the wage distribution based on initial position in 1986, and the results are presented in the columns of Table 3. Evidently, displacement has different consequences for low-wage and high-wage employees. Although more workers are displaced from the low-wage end of the wage distribution, the coefficient on displacement is positive and significant for the first quartile. Workers in the second quartile have $13.5 \%$ lower wage growth, in the third quartile $18 \%$ and in the upper quartile $31.6 \%$ lower wage growth. It is unlikely that the results are related to mismeasurement of the displacement variable, since this would presumably bias estimates towards zero.

Table 3 also presents alternative estimates of displacement wage loss. Besides including the the dichotomous indicator of predicted displacement as a regressor, we included instead the value of displacement probit itself as a regressor (specification iii); alternatively, the imputed displacement dummy variable was instrumented with the probit value itself (specification iv). Results obtained using the IV procedure are very close to the OLS estimates. The last specification (v) reported in Table 3 repeats specification (iii) with all reemployed workers who became unemployed in 1986 (without recalls). A similar picture emerges here too, albeit with smaller wage losses.

\section{Robustness Tests: How Good is the Two-Stage Imputation Procedure?}

\subsection{Sensitivity Analysis of the Displacement Definition}

The results reported so far were based on the following rule: all workers with predicted probabilities above 0.46 - the percentage of displaced workers in the sample used to estimate the probit - count as displaced. In order to test whether the results are sensitive to the cutoff level, tests were performed using alternatives values of $30 \%, 40 \%, 50 \%$ and $60 \%$. The results using $40 \%$ and $50 \%$ were very close to those at $46 \%$ and are not reported. Figure 3 (panel A) shows what happens to the numerical values of wage losses when the cutoff level varies more strongly. Estimated wage losses appear positively correlated with the cutoff level, which we interpret as evidence of important differences between workers with low and high displacement probabilities. 


\subsection{Including Displacement without Intervening Unemployment}

The probit analyis so far was based on a definition that included only movers with subsequent intervening unemployment (hereafter "Probit 1"). This definition seemed reasonable because most workers in the GSOEP who report displacement experience some unemployment, while only $8 \%$ of movers without unemployment report displacement. This definition may, however, impart a negative bias on the estimated wage losses, because workers who do not experience unemployment subsequent to displacement would also seem less likely to experience wage loss in their new jobs. In the following an alternative probit is estimated using all movers (hereafter "Probit 2"). ${ }^{13}$

Table 4 compares estimated wage losses in the IABS on the basis of both probits again excluding recalls. From each probit, movers are predicted as displaced when their probability of being displaced exeeds the proportion of displaced workers in the sample, i.e. 0.46 in Probit 1 and 0.20 in Probit 2. The Probit 1 classification yields considerably higher wage losses of, for example, up to around $30 \%$ for the upper quartile compared with roughly $8 \%$ using Probit 2. As argued earlier, Probit 1 is likely to overestimate wage losses, if human capital depreciates during unemployment, if unemployment conveys a negative signal leading to lower starting wages in new jobs, or if the best workers simply do not pass through unemployment. Lower wage losses are estimated with Probit 2 because some quits into unemployment are misclassified as displacement, leading to underestimation of actual loss. Where reality lies can be assessed using actual sample information in the GSOEP in the following section.

\subsection{Displaced Workers' Wage Growth in the German Socioeconomic Panel}

Although the GSOEP provides detailed longitudinal information on displacement status of unemployed workers, it is impossible to conduct credible mobility analyses of displaced workers due to the limited number of observations. ${ }^{14}$ This problem arises because much of the job information in the GSOEP is based on the current job. If the respondent is unemployed at the time of the interview in a given year, it is impossible to find out any detailed information on past or future jobs the same year.

In the following we will show what can be inferred from the information in the

\footnotetext{
13 Table A3 in the Appendix compares the two probits for the most preferred specification. Both probits perform reasonably well in explaining displacement and are relatively similar, despite some differences in parameter estimates and significance levels.

14 Only 3144 full-time workers (German and foreign, male and female) with valid information on important covariates like industry affiliation and schooling are identified as movers over a time span of 10 years. Of those workers under $50 \%$ are observed in a full-time job with valid wage observations in two consecutive years. Focusing on displaced workers, the number decreases further to 183 observations.
} 
GSOEP. First, we estimated simple year-to-year growth in hourly wages of full-time working males (German and foreign) for the following groups: stayers, all movers, all displaced workers, displaced workers with unemployment experience and workers predicted as displaced by the probit equations. Therefore we had to pool two-year panels $(85-86,86-87$ and so forth) into one dataset due to the limited number of observations; results can be found in Table A4 in the appendix. The consistent message from that experiment is that movers experience higher wage growth than stayers on average, but displaced workers' pay increases are only half of stable workers' wage growth. We also used the two different probits to predict displacement in the GSOEP itself. Recall that Probit 1 is based only on observations of movers unemployed for at least one month until reemployment and Probit 2 is based on all movers whether temporarily unemployed or not. While neither of the two probits performs perfectly, the predicted bias is born out by the empirical results. Probit 1 estimates too few workers as displaced and seems to underestimate wage growth and hence overestimate wage loss in comparsion with stable employed workers. However, Probit 2 estimates too many workers as displaced and overestimates wage growth, hence underestimates wage loss.

Finally, we estimated pooled wage growth regressions, including year dummies that should control for diverging average wage growth across years. The control group used is always the same (uninterrupted employment). Table 4 reports the results: the first row reports estimates for those displaced workers who experience some unemployment. The second row shows estimates with all displaced workers irrespective of unemployed between jobs and the last two rows show the estimates using displaced workers predicted from the two different probits. Dividing the sample into quartiles reduces the number of displaced observations considerably and displacement dummies are not always significant. Nevertheless, the results exhibit the same pattern found in the IABS: wage growth losses increase with average wages, with the best evidence from Probit 2, in which all movers were included. If anything, these results suggest that the wage growth regression based on Probit 1 overestimate wage losses.

\section{<Table 4 about here $>$}

\subsection{Is it merely regression towards the mean?}

One interpretation of our results is that wage patterns we infer for workers classified as displaced simply reflect a regression-to-the-mean phenomenon seen in Galton's Paradox and related phenomena. In order to consider this hypothesis more directly, we compare directly the distribution of wage changes for the displaced versus simply unemployed or others. Kolmogoroff-Smirnoff tests support our contention that our procedure has indeed identified something in the data which is statistically significant. First, the wage growth distribution of displaced workers is significantly different from workers without employment change, as can be seen from the Kolmogorov-Smirnov two-sample test-statistic including recalls: $\mathrm{KS}=7.90812$ with a p-value of 0.0001 , and excluding recalls: $\mathrm{KS}=7.27518$ with a p-value of 
0.0001. Second, the wage growth distribution of displaced workers also differs significantly from those of non-displaced unemployed workers, with respective test statistics of $\mathrm{KS}=4.34957$ and p-value 0.0001 including recalls, and $\mathrm{KS}=1.719708$ and p-value 0.0054 excluding recalls. Moreover, our results showed wage losses not only for the upper two quartiles, but also for the second quartile. The weight of the evidence does not support the assertion that post-displacement wage behavior is merely regression to the mean.

\subsection{Summary}

In sum, we have tested the robustness of our imputation procedure in a number of different ways. Pattern of wage loss for imputed displacement are robust to the selection procedure, and evidence from the GSOEP substantiates the findings that wage losses from displacement are lower on average in Germany than in the United States and that losses increase over the wage distribution. A range of plausible results for wage losses for the quartiles were estimated on the basis of two different probits using i) all movers reporting displacement and ii) those experiencing unemployment after leaving their old job. The latter method is likely to overestimate wage losses, since it excludes more successful displaced workers; the former will tend to misclassify voluntary moves as displacement and overweights those who erroneously classify themselves as displaced or who were able to anticipate their displacement well in advance. Estimates of wage losses for the upper quartile range from $8 \%$ using method i) to roughly $30 \%$ for method ii).

\section{Extensions}

\subsection{Persistence of Post-Displacement Wage Losses}

As other research has shown, wage losses associated with displacement need not be permanent. We thus estimated wage growth from 1986 to years 1987-1990 and are able to show that wage losses of high wage workers are persistent even four years following the displacement (this result holds irrespective of whether or not recalls are excluded). ${ }^{15}$ However, another explanation of our results is that workers differ from the control group by unobserved characteristics that influence wage growth. Controlling for individual heterogeneity by including absolute frequencies of unemployment spells, while significant, did not significantly change estimated wage losses.

Individual heterogeneity may have been responsible for wage growth prior to 1986 as well (see Jacobsen et al. 1993 for the United States). Column 1 of Table 5 reports estimates of wage growth regressions for 1985 to 1986; they show that workers on average do in fact have

\footnotetext{
15 See Table A5 in the Appendix.
} 
lower wage growth before displacement, but the estimated effect of the displacement dummy is much smaller pre-displacement than post-displacement: $-10 \%$ for the upper quartile and $-1 \%$ for the lowest quartile. Including the number of previously observed unemployment spells in these regressions does not significantly alter the results. Evidently, displaced workers not only face lower wage growth than continuously employed workers following displacement, but also slightly lower wage growth before separation.

\section{<Table 5 about here $>$}

\subsection{Wage Growth, Industrial Mobility and Industry Tenure}

Table 3 showed that wage losses for the upper three quartiles are lower for workers classified as displaced but subsequently reemployed by their previous employer (recalled). One possible explanation for this are returns to firm specific human capital, which are presumably recoverable upon recall. We included an interaction between imputed displacement and the incidence of recall, as well as one between imputed displacement with industry switching. The results reported in Table 5 indicate that recalled workers in the upper three quartiles indeed have higher wages than reemployed workers who are not recalled to their old firm. Moreover, from 1988 onwards, industry movers generally have lower wage growth than stayers even in the first wage quartile. This result can be seen as evidence for industryspecific human capital or industry rents lost when switching industries. It appears that workers who switch between industries in Germany are most often forced to do so and suffer wage losses as a consequence. For the upper three quartiles, this is confirmed by a robust negative estimate of 7.4-9.8 log points for displaced industry switchers and a positive estimate as high as $24.8 \log$ points for recalls.

If job tenure contributes to the accumulation of specific human capital, higher tenure should be correlated with larger wage losses. If, however, wage gains are due to industryspecific capital, then displacement should only affect future wage growth when workers switch industries. When both recalls and workers with less than one year of tenure are excluded from the displacement group, the number of workers with imputed displacement declines to 604; evidently this phenomenon is rare in western Germany, with unstable employment relationships concentrated in a small segment of the labor market. ${ }^{16}$ The last column in Table 5 reports results for regressions with interaction terms between displacement dummy and both previous industry tenure as well as firm tenure. Wage losses increase with 
industry tenure when looking at the average of all workers, but this effect is less uniform from the perspective of individual quartiles. Even more surprising is the fact that previous firm tenure seems to increase wage rates of displaced workers. At the same time, the recall interaction becomes negative for the first quartile. If recalled workers have higher previous tenure, this interaction might simply pick up some of the recall effects. Firm tenure interactions remain significant, however, even if recalled workers are excluded. Other interpretations of this effect can only be speculative, but matching and search theory gives good reason to expect a positive correlation between firm tenure and productivity. Hence, if high productivity workers accrued longer tenures on their old jobs and found better matches when reemployed, then a positive interaction might be expected. Learning about the complex relationships between tenure, wages, and productivity from the rich working histories of displaced workers will be left to future research.

\section{Conclusion}

Our most important findings can be grouped into two categories: first, those concerning observable factors associated with displacement, and second, the consequences of displacement for reemployment earnings. With regards to the former, we largely confirm results reported by Blau and Kahn (1981), in which age, tenure, industry and business cycle factors are significantly associated with displacement. Displacement is also higher in construction, trade, manufacturing and services, which is also consistent with US evidence. On the other hand, displacement is particularly low in the most regulated industries in Germany, energy, mining and the state sector, but also in credit and insurance.

A central finding is that German workers displaced in 1986 experienced significantly lower wage growth loss upon reemployment than estimated in the United States. At the same time, sample stratification reveals distinct differences for low and high wage workers: while wage growth for displaced workers in the lowest quartile in comparison with other low wage workers is marginally higher, high wage workers in the upper three quartiles exhibit losses of around $17 \%$ on average. While the latter figure is comparable to the wage losses estimated in the US, displacement occurs primarily in the lower segment of the wage distribution. This finding is certainly related to the evolution of measured wage inequality, which is low in Germany (Davis 1992) and is likely related to institutional factors described in Blau and Kahn (1996). ${ }^{17}$ Moreover, our tentative results on longer term wage growth point, like findings in

\footnotetext{
16 Wage growth regressions yield very similar results to the ones above and are not reported.

17 Along similar lines, Kuhn and Sweetman (1998) report that displaced workers losing union status experience higher wage losses than those who do not.
} 
the US, to "scarring" with respect to wages, suggesting that some aspects of the employment relationship are permanently destroyed in the displacement process.

Could it really be the case that fewer are displaced in Germany and have lower wage losses? This apparent "win-win" impression is deceptive, especially when one considers reemployment probabilities for those who are long-term unemployed after displacement. ${ }^{18}$ As only around $80 \%$ of all displaced workers are observed in socially insured employment even four years following the displacement, it seems more likely that Germans have achieved lower wage losses upon displacement at the cost of lower reemployment probabilities, raising once again the issue of the distribution of the burden of unemployment and adjustment. In this sense, the hypothesis put forward by Ljungqvist and Sargent (1998) seems to receive support at the microeconometric level.

Noteworthy is also our finding of high industrial and occupational mobility rates among displaced workers in Germany of around 33\%. Average overall mobility rates are much lower in the sample at around 6\%. Displaced workers seem to carry the burden of adjustment - incentives to move do not appear to be particularly strong so that workers only move when they are forced to by displacement. Mobility rates decrease with firm tenure, but not so much with potential labor market experience. As firm tenure is highly correlated with both industrial and occupational tenure, this finding is consistent with the accumulation of specific capital.

Displaced workers exhibit a pattern of lower wage growth than the average unemployed worker, regardless of whether two groups are stratified by education, tenure or potential experience. Particularly, post-displacement wage growth for workers with high potential labor market experience is lower than that for all unemployed workers with the same level of experience. These clear differences between all unemployed and displaced workers, combined with the finding of wage growth losses for high wage workers which resemble those in the US, lends support to the plausibility of our means of distinguishing between the two groups.

18 We are grateful to Christopher Ruhm for pointing this out to us. 


\section{References}

Abraham, Katharine G. and Henry Farber (1987), "Job Duration, Seniority, and Earnings", American Economic Review, 77 (3): 278-297.

Ackum, Susanne (1991), "Youth Unemployment, Labor Market Programs and Subsequent Earnings", Scandinavian Journal of Economics, 93 (4), 531-543.

Addison, John T. and Portugal, Pedro (1989), "Job displacement, relative wage change and duration of unemployment ", Journal of Labor Economics, 7 (3): 281-302.

Altonji, Joseph G. and Shakotko, Robert A. (1987), " Do Wages Rise with Job Seniority? ", Review of Economic Studies, 54: 431-459.

Altonji, Joseph G. and Williams, Nicolas (1992), " The Effects Of Labor Market Experience, Job Seniority, and Job Mobility on wage growth ", NBER working paper \#4133.

Bartel Ann P. and George J. Borjas (1981), "Wage Growth and Job Turnover: An Empirical Analysis", in Sherwin S. Rosen (ed.), Studies in Labor Markets, University of Chicago Press for National Bureau of Economic Research: 65-90.

Bender, Stefan and Jürgen Hilzendegen (1995), "Die IAB-Beschäftigtenstichprobe als scientific use file", Mitteilungen aus der Arbeitsmarkt- und Berufsforschung, 1/95: 79-95.

Blau, Francine, and Lawrence H. Kahn (1981), "Causes and Consequences of Layoffs," Economic Inquiry, 19 (April): 270-296.

Blau, Francine, and Lawrence H. Kahn (1996), "International Differences in Male Wage Inequality: Institutions versus Market Forces", Journal of Political Economy, 104 (4): 791-837.

Buttler, Friedrich and Lutz Bellmann (1991), "Mikroanalyse des Arbeitsmarktes mit Individualdaten der Sozialversicherungsträger: Einkommensverluste bei Freisetzungen", Ifo-Studien-Zeitschrift für empirische Wirtschaftsforschung, 37, 297-314.

Branson William and Julio Rotemberg (1980), "International Adjustment with Wage Rigidity", European Economic Review, 13 (3): 750-777.

Bruno, Michael and Jeffrey Sachs (1985), Economics of Worldwide Stagflation, Cambridge Mass.: Harvard University Press.

Carrington, William J. (1993), "Wage Loses for Displaced Workers Is It Really the Firm that Matters ?", The Journal of Human Resources, 52 (3): 435-462.

Davis, Steven J. (1992) "Cross-Country Patterns of Change in Relative Wages," NBER Macroeconomics Annual, 7: 239-291.

Dustmann, Christian and Costas Meghir (1997), "Seniority and Wage Growth", Institute for Fiscal Studies and University College London, mimeo.

Dustmann, Christian, Costas Meghir and Stefan Bender (1998), "Job Displacement, Non-employment and Wages in Germany", ", Institute for Fiscal Studies and University College London, mimeo.

Ehrenberg, Ronald and Robert Smith (1991) Modern Labor Economics: Theory and Public Policy Fourth edition. New York: HarperCollins.

Fallick, Bruce C.(1996), " A review of the recent empirical literature on displaced workers ", Industrial and Labor Relations Review 50 (1): 5-16.

Farber, Henry S. (1993), " The incidence and costs of job loss: 1982-91 ", Brooking Papers: Microeconomics 1993: 73- 132.

Farber, Henry S. (1997), "The Changing Face of Job Loss in the United States, 1981-1995", ", Brooking Papers: Microeconomics 1997: 55- 142.

Filer, Randall., Dan Hamermesh and Albert Rees (1996) The Economics of Work and Pay New York: HarperCollins.

Gerlach, Knut and Ulrich Schasse (1990), "Arbeitsmarktwirkungen von Kündigungen und Entlassungen", in Knut Gerlach and Olaf Hübler, Betriebszugehörigkeitsdauer und Mobilität - Theoretische und Empirische Analysen, Arbeitspapier 1990-4 aus dem SAMF: 121-142. 
Gregory, Mary and Robert Jukes (1997), "The Effects of Unemployment on Subsequent Earnings: A Study of British Men 1984-94", CEP Discussion Paper Series on the Labour Market Consequences of Technical and Structural Change No. 21.

Hall, Robert E. (1995), "Lost Jobs", Brookings Papers on Economic Activity, 1995 (1): 221-273.

Halvorsen, Robert and Raymond Palmquist (1980), "The Interpretation of Dummy Variables in Semilogarithmic Equations", American Economic Review, 70 (3): 474-475.

Hamermesh, Daniel S. (1987), " The costs of worker displacement ", Quarterly Journal of Economics, 28 (1): 51-75.

Hamermesh, Daniel S. (1989), "What do we Know about Worker Displacement in the United States?", Industrial Relations, 28 (1): 51-59.

Jacobson, Louis S., Robert LaLonde and Daniel G. Sullivan (1993), " Earnings Losses of Displaced Workers", The American Economic Review, 83 (4):685-709.

Kletzer, Lori G. (1989), " Returns to Seniority After Permanent Job Loss", The American Economic Review, 79 (3): 536-543.

Kletzer, Lori G. (1991), "Earnings after Job Displacement: Job Tenure, Industry, and Occupation ", in John T. Addison (ed.), Job Displacement, Wayne State University Press: 107-161.

Kletzer, Lori G. (1996), "The role of sector-specific skills in postdisplacement earnings ", Industrial Relations, 35 (4): 473-490.

Kletzer, Lori G. (1998), "Job Displacement", Journal of Economic Perspectives, 12 (1), 115-136.

Kuhn, Peter and Sweetman, Arthur (1998), "Wage Loss Following Displacement: The Role of Union Coverage", Industrial and Labor Relations Review, 51(3), 384-400.

Leonard, Jonathan and Van Audenrode, Marc (1995), " The Duration of Unemployment and the Persistence of Wages", CEPR Discussion Paper No.1227 Abstract.

Ljungqvist, Lars and Thomas J.Sargent (1998), "The European Unemployment Dilemma", Journal of Political Economy, 106 (3), 514-50.

Mavromaras Kostas G. and Helmut Rudolph (1995), "Recalls - Wiederbeschäftigung im alten Betrieb", Mitteilungen aus der Arbeitsmarkt- und Berufsforschung, 2/95: 171-194.

Mertens, Antje (1997), "Industrielle und berufliche Mobilität - Eine Untersuchung auf Basis der IABBeschäftigtenstichprobe", Mitteilungen aus der Arbeitsmarkt- und Berufsforschung, 3/97, 663-670.

Mertens, Antje (1998), Labor Mobility and Wage Dynamics - An Empirical Study for Germany in Comparison with the United States, Ph.D. Thesis Humboldt-University and Aachen: Shaker.

Mincer, Jacob and Boyan Jovanovic (1981), "Labor mobility and wages ", in Sherwin Rosen (ed.), Studies in Labor Markets, Chicago: University of Chicago Press for National Bureau of Economic Research: 2163.

Murphy, M. Kevin and Robert H. Topel (1985), "Estimation and Inference in Two-Step Econometric Models", Journal of Business and Economic Statistics 3 (4), 370-379.

Pichelmann, Karl and Monika Riedel (1993), "Unemployment Duration and the Relative Change in Individual Earnings: Evidence from Austrian Panel Data", Research Memorandum No. 317, Institute for Advanced Studies, Vienna.

Podgursky, Michael and Swaim, Paul (1987), " Job Displacement And Earnings Loss: Evidence From the Displaced Worker Survey ", Industrial And Labor Relations Review, 41 (1): 17-29.

Rohwer, Götz (1995), "Einführung in das praktische Arbeiten mit der IAB-Stichprobe", Papier erstellt für den Workshop des ZUMA, Mannheim, mimeo.

Ruhm, Christopher J. (1987), " The Economic Consequences Of Labor Mobility ", Industrial And Labor Relations Review, 41 (1): 30-49.

Ruhm, Christopher J. (1990), " Do earnings increase with job seniority ? ", Review of Economics and Statistics, 72 (Feb): 143-147.

Ruhm, Christopher J. (1991), " Are Workers Permanently Scarred by Job Displacements?", The American Economic Review, 81 (1): 319-324. 
Sachs, Jeffrey (1979), "Wages, Profits and Macroeconomic Adjustment: A Comparative Study", Brookings Papers on Economic Activity, 2: 269-319.

Sachs, Jeffrey (1983), "Real Wages and Unemployment in the OECD Countries," Brookings Papers on Economic Activity, 1: 255-304.

Swaim, Paul L. and Michael J. Podgursky (1991), "Displacement and Unemployment", in John T. Addison (ed.), Job Displacement, Wayne State University Press: 136-161.

Topel, Robert H. (1991), " Specific Capital, Mobility, and Wages: Wages Rise with Job Seniority ", Journal of Political Economy, 99 (1): 145-176.

Topel, Robert H. and Michael P. Ward (1992), "Job Mobility and the Careers of Young Men", Quarterly Journal Of Economics, 107 (2): 445-479. 


\section{Tables}

Table 1 - Job Mobility in the GSOEP 1985-1994: How Did Your Previous Job End?

\begin{tabular}{|l|cc|}
\hline & $\begin{array}{c}\text { Workers without } \\
\text { unemployment }\end{array}$ & $\begin{array}{c}\text { Workers with some } \\
\text { unemployment }\end{array}$ \\
\hline Percent of total workers & $(\mathrm{n}=2185)$ & $(\mathrm{n}=959)$ \\
\hline Made redundant & $8.8 \%$ & $45.9 \%$ \\
Fixed term contract ended & $3.7 \%$ & $10.4 \%$. \\
Quit & $44.3 \%$ & $22.9 \%$ \\
Mutually agreed termination of & $2.9 \%$ & $4.6 \%$ \\
employment & & \\
Other & $40.3 \%$ & $16.2 \%$ \\
\hline
\end{tabular}

Note: The sample includes all employees who report a job change with known type of change. Workers reporting to have been civil servants, self-employed or apprentices were excluded, as were those with missing values for variables used in the probit analysis below and private households, non-profit organizations and agriculture (including forestry and fisheries). Source: Own calculations from the GSOEP. 
Table 2 - Displacement Probits in the GSOEP for Full-Time Workers (1985-1994) ${ }^{+}$

\begin{tabular}{|c|c|c|c|c|c|}
\hline & $\mathrm{I}^{1}$ & $\mathrm{II}^{1}$ & $\mathrm{III}^{1}$ & $\mathrm{IV}^{1}$ & $\mathrm{~V}^{1}$ \\
\hline Constant & $\begin{array}{c}-0.2621 \\
(0.2759)\end{array}$ & $\begin{array}{l}-0.2575 \\
(0.2843)\end{array}$ & $\begin{array}{c}-1.0993 * * \\
(0.3941)\end{array}$ & $\begin{array}{c}-0.8794 * \\
(0.4139)\end{array}$ & $\begin{array}{c}-0.7732^{+} \\
(0.4258)\end{array}$ \\
\hline Age & $\begin{array}{c}0.0018 \\
(0.0055)\end{array}$ & $\begin{array}{c}0.0013 \\
(0.0055)\end{array}$ & $\begin{array}{c}0.0015 \\
(0.0056)\end{array}$ & $\begin{array}{c}0.0018 \\
(0.0057)\end{array}$ & $\begin{array}{c}0.0019 \\
(0.0057)\end{array}$ \\
\hline Age $*$ technical training & $\begin{array}{l}0.0141 * \\
(0.0069)\end{array}$ & $\begin{array}{l}0.0142 * \\
(0.0069)\end{array}$ & $\begin{array}{l}0.0138^{*} \\
(0.0070)\end{array}$ & $\begin{array}{c}0.0155^{* *} \\
(0.0071)\end{array}$ & $\begin{array}{l}0.0156^{*} \\
(0.0071)\end{array}$ \\
\hline Age * university & $\begin{array}{l}-0.0086 \\
(0.0262)\end{array}$ & $\begin{array}{c}-0.0074 \\
(0.0264)\end{array}$ & $\begin{array}{l}-0.0121 \\
(0.0260)\end{array}$ & $\begin{array}{c}-0.0188 \\
(0.0267)\end{array}$ & $\begin{array}{l}-0.0201 \\
(0.0267)\end{array}$ \\
\hline Foreigner & $\begin{array}{l}0.2239^{*} \\
(0.0974)\end{array}$ & $\begin{array}{l}0.2388^{*} \\
(0.0979)\end{array}$ & $\begin{array}{l}0.2469^{*} \\
(0.0993)\end{array}$ & $\begin{array}{c}0.3027 * * \\
(0.1019)\end{array}$ & $\begin{array}{l}0.3015^{*} \\
(0.1019)\end{array}$ \\
\hline Technical training & $\begin{array}{c}-0.6112 * \\
(0.2619)\end{array}$ & $\begin{array}{l}-0.6208^{*} \\
(0.2625)\end{array}$ & $\begin{array}{c}-0.6417 * \\
(0.2661)\end{array}$ & $\begin{array}{c}-0.7219 * * \\
(0.2708)\end{array}$ & $\begin{array}{c}-0.7235^{* *} \\
(0.2709)\end{array}$ \\
\hline University & $\begin{array}{l}-0.0731 \\
(0.9680)\end{array}$ & $\begin{array}{c}-0.0574 \\
(0.9741)\end{array}$ & $\begin{array}{c}0.1736 \\
(0.9741)\end{array}$ & $\begin{array}{c}0.3249 \\
(1.0013)\end{array}$ & $\begin{array}{c}0.3736 \\
(1.0032)\end{array}$ \\
\hline Blue collar with techn. training & $\begin{array}{c}0.0539 \\
(0.1172)\end{array}$ & $\begin{array}{c}0.0236 \\
(0.1181)\end{array}$ & $\begin{array}{c}-0.0286 \\
(0.1225)\end{array}$ & $\begin{array}{c}-0.0218 \\
(0.1252)\end{array}$ & $\begin{array}{l}-0.0135 \\
(0.1255)\end{array}$ \\
\hline Foremen, master & $\begin{array}{c}0.0794 \\
(0.4595)\end{array}$ & $\begin{array}{c}0.0272 \\
(0.4654)\end{array}$ & $\begin{array}{c}0.0166 \\
(0.4731)\end{array}$ & $\begin{array}{c}0.1352 \\
(0.4757)\end{array}$ & $\begin{array}{c}0.1555 \\
(0.4757)\end{array}$ \\
\hline White Collar & $\begin{array}{c}-0.2642 * \\
(0.1189)\end{array}$ & $\begin{array}{c}-0.2897^{*} \\
(0.1201)\end{array}$ & $\begin{array}{l}-0.2011 \\
(0.1299)\end{array}$ & $\begin{array}{c}-0.1932 \\
(0.1319)\end{array}$ & $\begin{array}{l}-0.1981 \\
(0.1321)\end{array}$ \\
\hline Job duration 0-3 years & $\begin{array}{c}0.1687 \\
(0.1380)\end{array}$ & $\begin{array}{c}0.1315 \\
(0.1396)\end{array}$ & $\begin{array}{c}0.1387 \\
(0.1428)\end{array}$ & $\begin{array}{c}0.2212 \\
(0.1457)\end{array}$ & $\begin{array}{c}0.2218 \\
(0.1458)\end{array}$ \\
\hline Job duration 3-10 years & $\begin{array}{c}0.1836 \\
(0.1301)\end{array}$ & $\begin{array}{c}0.1621 \\
(0.1310)\end{array}$ & $\begin{array}{c}0.1836 \\
(0.1330)\end{array}$ & $\begin{array}{c}0.2106 \\
(0.1352)\end{array}$ & $\begin{array}{c}0.2151 \\
(0.1354)\end{array}$ \\
\hline Small firm & & $\begin{array}{l}0.2085^{*} \\
(0.1034)\end{array}$ & $\begin{array}{l}0.1809^{+} \\
(0.1067)\end{array}$ & $\begin{array}{c}0.1685 \\
(0.1104)\end{array}$ & $\begin{array}{c}0.1677 \\
(0.1104)\end{array}$ \\
\hline Large firm & & $\begin{array}{l}-0.0547 \\
(0.1020)\end{array}$ & $\begin{array}{c}0.0334 \\
(0.1060)\end{array}$ & $\begin{array}{c}-0.0142 \\
(0.1085)\end{array}$ & $\begin{array}{c}-0.0078 \\
(0.1087)\end{array}$ \\
\hline Manufacturing & & & $\begin{array}{c}0.7636^{* *} \\
(0.2680)\end{array}$ & $\begin{array}{c}0.7837 * * \\
(0.2735)\end{array}$ & $\begin{array}{c}0.8164 * * \\
(0.2767)\end{array}$ \\
\hline Construction & & & $\begin{array}{c}1.1463^{* *} \\
(0.2886)\end{array}$ & $\begin{array}{c}1.1274 * * \\
(0.2951)\end{array}$ & $\begin{array}{c}1.1631 * * \\
(0.2986)\end{array}$ \\
\hline
\end{tabular}




\begin{tabular}{|c|c|c|c|c|c|}
\hline Table 2 continued & $\mathrm{I}^{1}$ & $\mathrm{II}^{1}$ & $\mathrm{III}^{1}$ & $\mathrm{IV}^{1}$ & $\mathrm{~V}^{1}$ \\
\hline Trade & . & . & $\begin{array}{l}0.7518^{*} \\
(0.2948)\end{array}$ & $\begin{array}{l}0.7468^{*} \\
(0.2999)\end{array}$ & $\begin{array}{l}0.7257 * \\
(0.3019)\end{array}$ \\
\hline Transport, communication & . & . & $\begin{array}{c}1.0873 * * \\
(0.3379)\end{array}$ & $\begin{array}{c}1.0947 * * \\
(0.3460)\end{array}$ & $\begin{array}{c}1.0832 * * \\
(0.3477)\end{array}$ \\
\hline Credit, insurance & . & . & $\begin{array}{c}-0.3831 \\
(0.5922)\end{array}$ & $\begin{array}{l}-0.3219 \\
(0.6116)\end{array}$ & $\begin{array}{c}-0.3492 \\
(0.6133)\end{array}$ \\
\hline Other services & . & . & $\begin{array}{c}0.8043 * \\
(0.2808)\end{array}$ & $\begin{array}{l}0.8150^{*} \\
(0.2856)\end{array}$ & $\begin{array}{l}0.7169 * \\
(0.2999)\end{array}$ \\
\hline Displacement 84 & . & . & & $\begin{array}{l}-0.1803 \\
(0.1563)\end{array}$ & $\begin{array}{c}-0.3052 \\
(0.1929)\end{array}$ \\
\hline Displacement 85 & . & . & . & $\begin{array}{l}-0.0451 \\
(0.1764)\end{array}$ & $\begin{array}{c}-0.1702 \\
(0.2090)\end{array}$ \\
\hline Displacement 86 & . & . & . & $\begin{array}{l}-0.1599 \\
(0.1817)\end{array}$ & $\begin{array}{l}-0.3169 \\
(0.2304)\end{array}$ \\
\hline Displacement 87 & . & . & . & $\begin{array}{l}-0.1985 \\
(0.1773)\end{array}$ & $\begin{array}{l}-0.3349 \\
(0.2158)\end{array}$ \\
\hline Displacement 88 & . & . & . & $\begin{array}{l}-0.1178 \\
(0.2025)\end{array}$ & $\begin{array}{l}-0.2614 \\
(0.2404)\end{array}$ \\
\hline Displacement 89 & . & . & . & $\begin{array}{l}-0.3512^{+} \\
(0.1902)\end{array}$ & $\begin{array}{c}-0.5224 * \\
(0.2449)\end{array}$ \\
\hline Displacement 90 & . & . & . & $\begin{array}{c}-0.8366^{* *} \\
(0.1917)\end{array}$ & $\begin{array}{c}-1.0814 * * \\
(0.2922)\end{array}$ \\
\hline Displacement 91 & . & . & . & $\begin{array}{c}-0.7166^{* *} \\
(0.1811)\end{array}$ & $\begin{array}{c}-0.9238^{* *} \\
(0.2602)\end{array}$ \\
\hline Displacement 92 & . & . & & $\begin{array}{c}-0.5146 * * \\
(0.1831)\end{array}$ & $\begin{array}{c}-0.6373 * * \\
(0.2141)\end{array}$ \\
\hline Industry employment growth & . & . & . & . & $\begin{array}{c}3.2005 \\
(2.8699)\end{array}$ \\
\hline Pseudo- $R^{2}$ & 6.9 & 8.0 & 13.2 & 18.8 & 19.1 \\
\hline
\end{tabular}

Note: ${ }^{1}=$ Dependent variable equals one if the mover has been made redundant and zero otherwise. Selection: all movers without workers having just completed their apprenticeship, formerly self-employed or former civil servants. Without agriculture, forestry, fisheries, private households and non-profit organizations. Previously full-time employed West Germans only. A ** indicates significance at the $1 \%$ level, $*$ at the $5 \%$ level and ${ }^{+}$at the $10 \%$ level. The reference groups are blue collar workers without technical training in the state or energy/mining sector with more than 10 years of tenure displaced in 1993 from a medium sized firm. Source: Own calculations based on the GSOEP. 
Table 3 - Estimated Coefficient on Displacement Dummy in Equations Predicting Wage Growth in 1986-1987

\begin{tabular}{|c|c|c|c|c|c|c|}
\hline & Specification & All worker & $1^{\text {st }}$ Quartile & $\begin{array}{c}\text { Sample } \\
2^{\text {nd }} \text { Quartile }\end{array}$ & $3^{\text {rd }}$ Quartile & $4^{\text {th }}$ Quartile \\
\hline Including recalls & i) OLS + Dummy ${ }^{a}$ & $\begin{array}{c}-0.0264 * * \\
(0.0020)\end{array}$ & $\begin{array}{c}0.0184 * * \\
(0.0039)\end{array}$ & $\begin{array}{c}-0.0674 * * \\
(0.0032)\end{array}$ & $\begin{array}{c}-0.1119 * * \\
(0.0040)\end{array}$ & $\begin{array}{c}-0.2033 * * \\
(0.0051)\end{array}$ \\
\hline Excluding recalls & ii) OLS + Dummy & $\begin{array}{c}-0.0364 * * \\
(0.0027)\end{array}$ & $\begin{array}{c}0.0187 * * \\
(0.0049)\end{array}$ & $\begin{array}{c}-0.1450 * * \\
(0.0049)\end{array}$ & $\begin{array}{c}-0.2013 * * \\
(0.0063)\end{array}$ & $\begin{array}{c}-0.3791 * * \\
(0.0077)\end{array}$ \\
\hline & iii) OLS + Probit ${ }^{\mathrm{b}}$ & $\begin{array}{c}-0.0621 * * \\
(0.0047)\end{array}$ & $\begin{array}{c}0.0380 * * \\
(0.0086)\end{array}$ & $\begin{array}{c}-0.2452 * * \\
(0.0085)\end{array}$ & $\begin{array}{c}-0.3386 * * \\
(0.0109)\end{array}$ & $\begin{array}{c}-0.6455 * * \\
(0.0132)\end{array}$ \\
\hline & iv) IV + Dummy ${ }^{c}$ & $\begin{array}{c}-0.0359 * * \\
(0.0027)\end{array}$ & $\begin{array}{c}0.0218 * * \\
(0.0050)\end{array}$ & $\begin{array}{c}-0.1442 * * \\
(0.0050)\end{array}$ & $\begin{array}{c}-0.1996 * * \\
(0.0064)\end{array}$ & $\begin{array}{c}-0.3806 * * \\
(0.0078)\end{array}$ \\
\hline Excluding recalls & v) OLS + Probit ${ }^{b, d}$ & $\begin{array}{c}-0.0519 * * \\
(0.0042)\end{array}$ & $\begin{array}{c}0.0450 * * \\
(0.0083)\end{array}$ & $\begin{array}{c}-0.2284 * * \\
(0.0073)\end{array}$ & $\begin{array}{c}-0.3204 * * \\
(0.0094)\end{array}$ & $\begin{array}{c}-0.5697 * * \\
(0.0107)\end{array}$ \\
\hline
\end{tabular}

Note: Wage growth regressions. Standard errors in parentheses. Sample (except otherwise stated): Workers estimated as displaced by a high enough probit score and control group of workers who work 365 days each year 1986 and 1987. Number of observations without recalls 74,302 (of which 1,356 displaced). Number of observations with recalls 75,821 (of which 2875 displaced). ** indicates significance at the $1 \%$-level. Other control variables are: age, age ${ }^{2}$, previous firm tenure, previous firm tenure ${ }^{2}$, education dummies, worker status dummies, firm size dummies and occupation dummies.

$\mathrm{a}=$ OLS: Dummy that equals 1 if worker is estimated as displaced.

$\mathrm{b}=$ OLS: Estimated probability for displaced workers is included directly. Murphy/Topel (1985) corrected standard errors are reported.

$\mathrm{c}=\mathrm{IV}$ : Displacement is instrumented with the estimated probability.

$\mathrm{d}=$ OLS: All unemployed workers and their estimated probability for displacement are included. 
Table 4 -Wage Growth Regressions in the GSOEP by Quartile

\begin{tabular}{|c|c|c|c|c|c|}
\hline & \multicolumn{5}{|c|}{ Sample } \\
\hline & All workers & $\mathbf{1}^{\text {st }}$ Quartile & $2^{\text {nd }}$ Quartile & $3^{\text {rd }}$ Quartile & $4^{\text {th }}$ Quartile \\
\hline $\begin{array}{l}\text { Displaced workers with some } \\
\text { unemployment experience }\end{array}$ & -0.0328 & -0.0085 & -0.0872 & -0.084 & -0.1605 \\
\hline Standard error & $(0.044)$ & $(0.065)$ & $(0.067)$ & $(0.081)$ & $(0.207)$ \\
\hline Observations (of which displaced) & $20461(78)$ & $5104(42)$ & $5128(20)$ & $5188(10)$ & $5044(6)$ \\
\hline All displaced workers & $-0.0468+$ & 0.0517 & $-0.0720+$ & $-0.1135 *$ & $-0.2618 *$ \\
\hline Standard error & $(0.031)$ & $(0.041)$ & $(0.049)$ & $(0.048)$ & $(0.110)$ \\
\hline Observations (of which displaced) & $20544(161)$ & $5134(72)$ & $5146(38)$ & 5057 & $5207(21)$ \\
\hline Predicted displaced - Probit1 & -0.0534 & -0.073 & -0.0571 & $-0.4641 * *$ & -0.0294 \\
\hline Standard error & $(0.056)$ & $(0.069)$ & $(0.095)$ & $(0.086)$ & $(0.253)$ \\
\hline Observations (of which displaced) & $20431(48)$ & $5087(25)$ & $5119(10)$ & $5186(9)$ & $5039(4)$ \\
\hline Predicted displaced - Probit2 & 0.0062 & $0.0980 * *$ & $-\mathbf{0 . 0 4 2 7}$ & $-0.0685 *$ & $-0.3354 * *$ \\
\hline Standard error & $(0.025)$ & $(0.032)$ & $(0.037)$ & $(0.049)$ & $(0.104)$ \\
\hline Observations (of which displaced) & $20632(249)$ & $5161(126)$ & $5155(69)$ & $5106(30)$ & $5210(249)$ \\
\hline
\end{tabular}

Note: Estimated coefficients on displacement dummies in wage growth regressions. Included are workers reported as displaced or estimated as displaced by the procedure described in the text and reemployed in the following year. The control group consists of workers who are continuously employed. Parameter estimates in Probit 1 are based on only those job movers who experience some unemployment. Probit 2 is based on all job movers. Other control variables: age, age ${ }^{2}$, gender dummy, foreigner dummy, education dummies, firm size dummies, tenure $\leq 1$ year dummy, year dummies, ** indicates significance at the $1 \%$ level, * at the $5 \%$ level and ${ }^{+}$at the $10 \%$ level.

Source: Own calculations using the GSOEP from 1985 to 1994. 
Table 5 - Wage Growth, Recall and Industry Movers

\begin{tabular}{|c|c|c|c|}
\hline & 1985-1986 & 1986-1987 & 1986-1987 \\
\hline \multicolumn{4}{|l|}{ All workers } \\
\hline displaced & $-0.0220 * *$ & $-0.0231 * *$ & $-0.0225 * *$ \\
\hline displaced $*$ industry move & . & $-0.0242 * *$ & $-0.0268 * *$ \\
\hline displaced $*$ recall & . & 0.0051 & -0.0033 \\
\hline displaced $*$ industry tenure & . & . & $-0.0034 * *$ \\
\hline displaced $*$ firm tenure & . & . & $0.0065^{* *}$ \\
\hline $\mathbf{1}^{\text {st }}$ Quartile & $-0.0095^{*}$ & & \\
\hline displaced & . & $0.0250 * *$ & 0.0070 \\
\hline displaced $*$ industry move & . & -0.0074 & -0.0050 \\
\hline displaced $*$ recall & . & -0.0097 & $-0.0287 * *$ \\
\hline displaced $*$ industry tenure & . & . & -0.0012 \\
\hline displaced $*$ firm tenure & . & . & $0.0112 * *$ \\
\hline \multicolumn{4}{|l|}{$2^{\text {nd }}$ Quartile } \\
\hline displaced & $-0.0348 * *$ & $-0.0929 * *$ & $-0.1206^{* *}$ \\
\hline displaced $*$ industry move & . & $-0.0981 * *$ & $-0.0909 * *$ \\
\hline displaced $*$ recall & . & $0.0725 * *$ & $0.0598 * *$ \\
\hline displaced $*$ industry tenure & . & . & $0.0046 * *$ \\
\hline displaced $*$ firm tenure & . & . & 0.0023 \\
\hline $\begin{array}{c}\mathbf{3}^{\text {rd }} \text { Quartile } \\
\text { displaced }\end{array}$ & $-0.0614 * *$ & $-0.1637 * *$ & $-0.1625 * *$ \\
\hline displaced $*$ industry move & . & $-0.0816^{* *}$ & $-0.0867 * *$ \\
\hline displaced $*$ recall & . & $0.0968 * *$ & $0.0808 * *$ \\
\hline displaced $*$ industry tenure & . & . & $-0.0056^{* *}$ \\
\hline displaced $*$ firm tenure & . & . & $0.0100 * *$ \\
\hline \multicolumn{4}{|l|}{$4^{\text {th }}$ Quartile } \\
\hline displaced & $-0.1103 * *$ & $-0.3448 * *$ & $-0.3522 * *$ \\
\hline displaced $*$ industry move & . & $-0.0740 * *$ & $-0.0732 * *$ \\
\hline displaced $*$ recall & . & $0.2488 * *$ & $0.2416^{* *}$ \\
\hline displaced $*$ industry tenure & . & . & -0.0015 \\
\hline displaced $*$ firm tenure & . & . & $0.0052 * *$ \\
\hline
\end{tabular}

Note: Dependent variable is the log wage differential. ** indicates significance at the $1 \%$-level and $*$ at the $5 \%$ level (one-sided test). Included are workers displaced in 1986 and employed in the year for which wage growth is calculated. The control group consists of workers who work 365 days each year during the time span of the respective wage growth regression. Other control variables are: age, age ${ }^{2}$, previous firm tenure, previous firm tenure $^{2}$, education dummies, worker status dummies, firm size dummies and occupation dummies. Source: Own calculations based on the IAB-sample. 


\section{Figures}

Figure 1 - Non-Employment Survivor Function

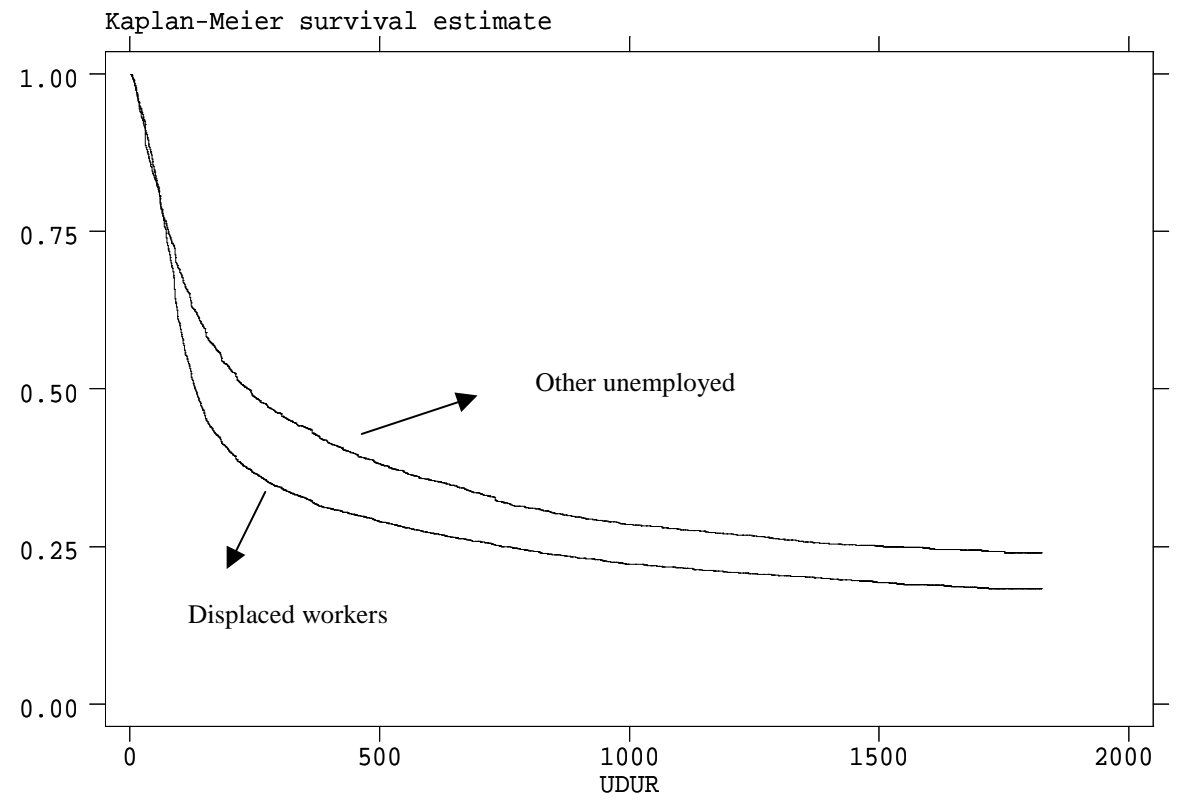

Note: UDUR=duration of non-employment spell following displacement or other transition into unemployment. The survivor function is defined as the probability that non-employment duration will be equal to or exeed a specific amount of days. Censoring point: 1825 days.

Source: Own calculations using the IAB Sample.

Figure 2 - Unemployment, displacement and wages

\section{Displacement and Wages}

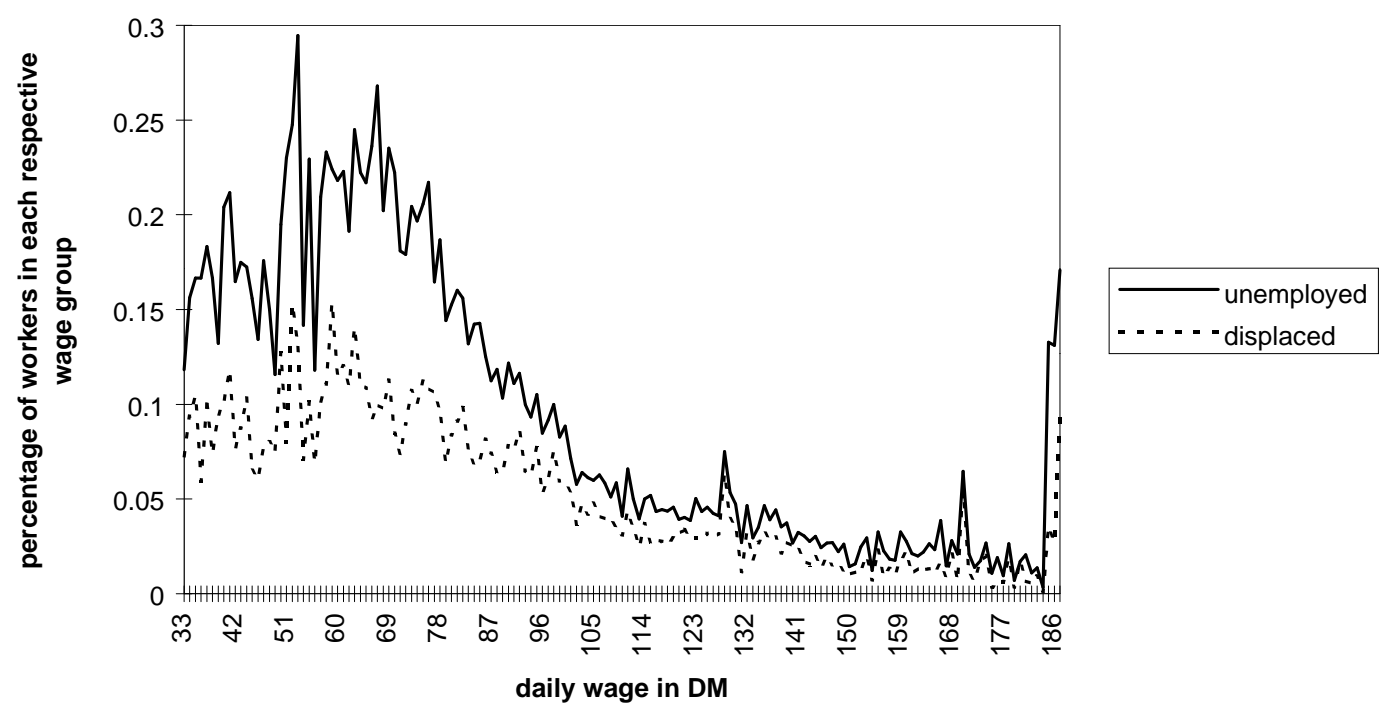

Note: Displaced workers are estimated from probit equations using the GSOEP. The graph shows displacement frequencies in different daily wage groups: displaced workers with daily wage " $\mathrm{x}$ " / all employees with daily wage "x". See text for details.

Source: Own calculations based on the IAB sample. 
Figure 3 - Sensitivity Analysis

Panel A

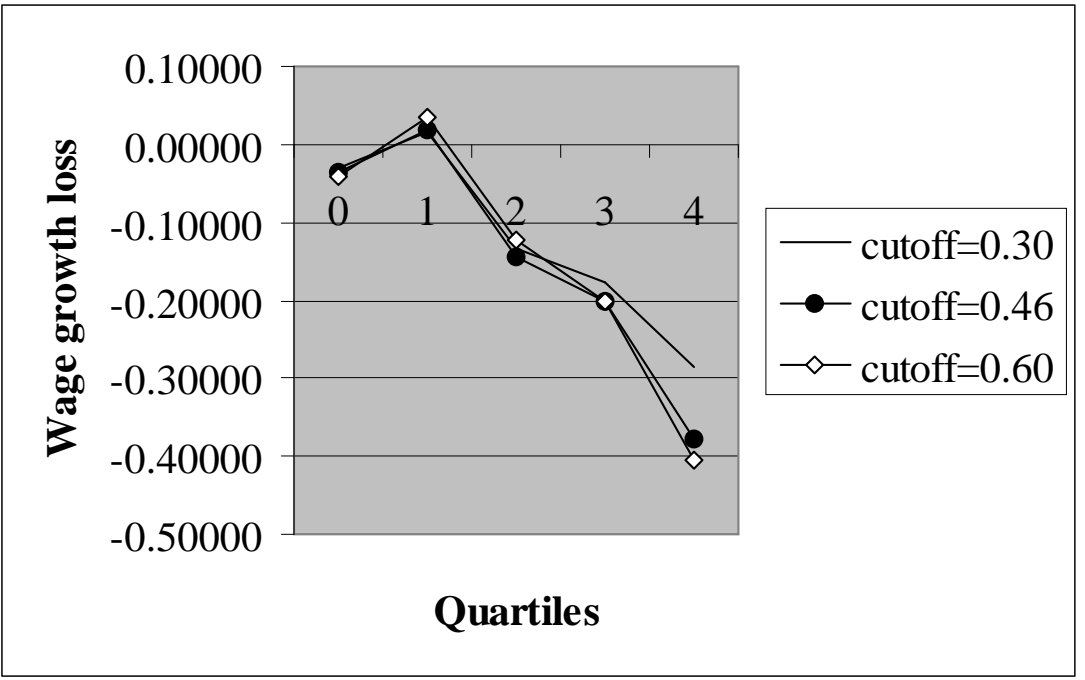

Panel B

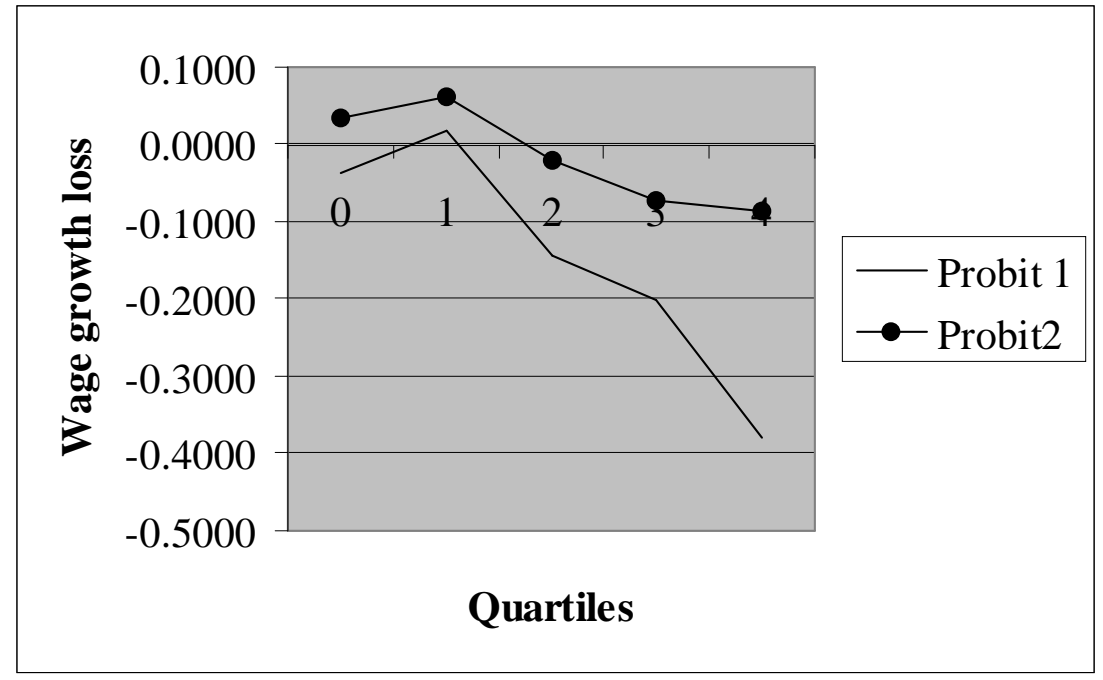

Note: In panel A the cutoff for predicted displacement is varied. In Panel B the Probit 1 is based on only those job movers who experience some unemployment. Probit 2 is based on all job movers. See the text for details. Source: Own calculations using the IAB sample. 


\section{Data Appendix}

\section{The German Socioeconomic Panel (GSOEP)}

The GSOEP is a panel of approximately 3600 West German households which has been conducted annually since 1984. All adults in participating households are interviewed once a year, usually in spring. The questions cover economic and social conditions of all household members. Of particular interest to this study is the fact that currently employed workers with changes in their job during the last year and workers who became unemployed during the previous year are asked about the nature of the job change or loss. When workers state that there was a change, they are then asked "How did your last spell of employment end?" Answers include layoff, end of fixed term contract, quit and mutual agreed termination of employment. ${ }^{19}$

For workers who changed jobs, the GSOEP contains retrospective information on the worker's previous employment relationship such as firm size, industry and occupation. The extraction of retrospective data is not trivial, and depends on when the interview took place and when the job is reported to have ended. The bulk of the interviews occur in the spring, but some interviews are held in almost every month of the year. Most questions we are interested in refer to the time of the interview like the industry or occupation of employed workers. Previous job information is only available for those workers who were employed at the last round of the interviews. Some of the unemployed workers became unemployed before that date and some currently employed workers might have been unemployed one year before, so workers must sometimes be traced back several waves.

For our purposes four cases can be distinguished: workers who are unemployed in the year of the interview $t$ and employed in $t-1\left(\mathrm{U}_{\mathrm{t}} \mathrm{E}_{\mathrm{t}-1}\right)$; workers unemployed in both years $\mathrm{t}$ and $\mathrm{t}-$ $1\left(\mathrm{U}_{\mathrm{t}} \mathrm{U}_{\mathrm{t}-1}\right)$; workers employed in $\mathrm{t}$ and $\mathrm{t}-1\left(\mathrm{E}_{\mathrm{t}} \mathrm{E}_{\mathrm{t}-1}\right)$; and workers employed in $\mathrm{t}$ but unemployed in $t-1\left(E_{t} U_{t-1}\right)$. Workers who were unemployed at the time of the interview in $t-1$, i.e. groups $\left(\mathrm{U}_{\mathrm{t}} \mathrm{U}_{\mathrm{t}-1}\right)$ and $\left(\mathrm{E}_{\mathrm{t}} \mathrm{U}_{\mathrm{t}-1}\right)$, must have lost their job before the interview that year. It is impossible that the job loss occurred in year $\mathrm{t}-2$, as the original question asks for job changes only within year t-1 up until to the interview date in t. For those workers, job information from year t- 2 is taken if available. For several reasons, information may be missing. The individual might not have been in the labor force at the interview time, she might have been unemployed and found a job later in year t-2, or she might have not participated in that wave. Multiple job changes may pose a problem if movers were unemployed at the time of the interview in $\mathrm{t}-1$, then found

19 In fact workers are asked, for example in March, whether their job changed since the beginning of the 
a job and lost it again before the interview in time t. It is impossible to obtain information on the characteristics of that job and therefore we have to neglect multiple job changes.

For group $\left(\mathrm{U}_{\mathrm{t}} \mathrm{E}_{\mathrm{t}-1}\right)$ retrospective information from time $\mathrm{t}-1$ is taken, as it is for group $\left(\mathrm{E}_{\mathrm{t}} \mathrm{E}_{\mathrm{t}-1}\right)$. Using information on the year and month of the reported job ending and on the time of the interview, it can be verified, whether this information is correct: if the job is reported to end before the interview in $\mathrm{t}-1$, then information on separation cannot be linked to the job in $\mathrm{t}$, but to the one in $\mathrm{t}-2$ ! Also in these cases job information for $\mathrm{t}-2$ is taken, if available. Further waves are not checked, as the likelihood of using the wrong job information due to multiple job changes increases.

\section{The German Social Security File (IAB)}

The second data set we employ is a large random sample drawn from the universe of west German social security records starting in 1973, when an integrated reporting procedure for unemployment, health insurance and pensions was introduced. ${ }^{20}$ Firms are required to report on all dependent employees paying social security contributions, including information on income, education, exact number of days worked, occupation, industry, worker status, nationality and marital status. Employers report on the initiation and termination of jobs as well as on all ongoing employment relationships at least once a year on December 31 . The $1 \%$-sample contains precise daily information on approximately 430,000 employees. Not included are civil servants, self-employed and workers earning wages below the compulsory social security threshold. The sample also contains information on receipt of unemployment benefit and income while participating in retraining programs. Hence, the individuals can be followed through non-employment spells as long as they are eligible for benefits paid by the Bundesanstalt für Arbeit. While the IAB panel has been increasingly recognized as a powerful instrument for labor market research, its structure and information content differ significantly from the GSOEP. Notwithstanding these differences, information from the two data sets can be made comparable for our purposes.

There are a number of noteworthy limitations of the IAB data set. First, it excludes self-employment as well as casual employment which falls under the minimum (Geringfügigkeitsgrenze, DM 620 per month in 1998) and thereby is exempt from social security contributions. Second, wages and salaries are censored above the maximum ceiling on which social security contributions must be paid. The cutoff-levels (Beitragsbemessungsgrenze) for the time span used in this paper rose from 4,700 DM per 
month in 1982 to $6,300 \mathrm{DM}$ in 1990 , but only under $10 \%$ of observations are usually at the cutoff level. These observations were deleted in our estimations. Third, privacy safeguards preclude the availability of regional information apart from a very crude measure of population density. Fourth, information on hours worked is unavailable. Finally, information on education is more aggregated and the individual information more limited than in other micro data sets such as the GSOEP

The IAB data identify moves of workers with day-to-day accuracy. Several types of moves exist and can be distinguished: (a) direct move from job to job, (b) move from job to job with an intervening spell without information about the worker, (c) between jobs with intervening spell of unemployment. If a workers moves from job to non- or unemployment without any further information he might have become self-employed or retired, dropped out of the labor force or died. In this paper, we are primarily interested in finding out the economic consequences for workers of group (c) who were involuntarily displaced. Group (b) is too heterogeneous to be considered: military service, children, unemployment without eligibility for benefits or any other voluntary break can be responsible. Certainly, there might be some workers in group (a) as well, who lost their job involuntarily, were notified in advance and managed to find a new job before they became unemployed, however, most of the job-to-job moves were not due to displacement. As can be seen from Table 1, the percentage of workers made redundant for those with some unemployment is $46 \%$, the percentage of workers made redundant for those without any unemployment is only $8.8 \%$. 


\section{Employing the Two Data Sets}

Because information on personal characteristics in the IAB sample is limited, personal covariates are defined broadly to include three different education levels (no technical training, technical training, university degree), job status in four categories (blue collar without training, blue collar with training, master/foremen, white collar), year of birth, and marital status. The breakdown of job specific characteristics like occupation and industry is limited by the small numbers of observations we have in the GSOEP. Because many smaller cells are otherwise empty, we were forced to use information at the one-digit level. Firm size categories are not completely conformable and are therefore placed in three broad categories: small (1-19), medium (20-99 in the IAB sample and 20-199 in the GSOEP) and large (100 and above or 200 and above respectively).

The IAB sample does contain information on hours worked, but only the fulltime/part-time distinction, so only full-time workers are included in the analysis. As described above in Section 2.1 the question "How did your previous job end?" in the GSOEP refers primarily to the year prior to the survey, so information is reported for displaced workers for not only a point in time, but over a time period. Consequently, we also look at those workers who become unemployed within a single year in the IAB sample, 1986. 


\section{Appendix-Tables}

Table A1 - Average Wage Growth by Sex

\begin{tabular}{|c|c|c|c|c|}
\hline & & Men & Women & Men and Women \\
\hline All employees ${ }^{1,2}$ & $\begin{array}{l}1986 \text { - } 1987 \\
\text { Standard deviation } \\
\text { Observations }\end{array}$ & $\begin{array}{c}\mathbf{0 . 0 4 2} \\
(0.122) \\
89,614\end{array}$ & $\begin{array}{c}\mathbf{0 . 0 5 9} \\
(0.128) \\
40,770\end{array}$ & $\begin{array}{c}\mathbf{0 . 0 4 7} \\
(0.124) \\
130,384\end{array}$ \\
\hline $\begin{array}{l}\text { Non-displaced workers with } \\
\text { unemployment beginning } 1986^{1,2}\end{array}$ & $\begin{array}{l}1986 \text { - } 1987 \\
\text { Standard deviation } \\
\text { Observations }\end{array}$ & $\begin{array}{c}\mathbf{0 . 6 3 2} \\
(0.256) \\
1,572\end{array}$ & $\begin{array}{c}\mathbf{0 . 0 8 6} \\
(0.261) \\
876\end{array}$ & $\begin{array}{c}\mathbf{0 . 0 7 1} \\
(0.264) \\
2448\end{array}$ \\
\hline Workers displaced $1986^{1,2}$ & $\begin{array}{l}1986 \text { - } 1987 \\
\text { Standard deviation } \\
\text { Observations }\end{array}$ & $\begin{array}{c}\mathbf{0 . 0 2 7} \\
(0.242) \\
2,875\end{array}$ & $\begin{array}{c}\mathbf{0 . 0 5 3} \\
(0.278) \\
457\end{array}$ & $\begin{array}{c}\mathbf{0 . 0 3 0} \\
(0.248) \\
3,332\end{array}$ \\
\hline $\begin{array}{l}\text { Non-displaced workers with } \\
\text { unemployment beginning } 1986^{3}\end{array}$ & $\begin{array}{l}\text { First new job } 1986 \\
\text { Standard deviation } \\
\text { Observations }\end{array}$ & $\begin{array}{c}\mathbf{0 . 0 4 2} \\
(0.277) \\
958\end{array}$ & $\begin{array}{c}\mathbf{0 . 0 5 0} \\
(0.249) \\
551\end{array}$ & $\begin{array}{c}\mathbf{0 . 0 4 5} \\
(0.267) \\
1509\end{array}$ \\
\hline & $\begin{array}{l}\text { First new job } 1987 \\
\text { Standard deviation } \\
\text { Observations }\end{array}$ & $\begin{array}{c}\mathbf{0 . 0 5 1} \\
(0.261) \\
761\end{array}$ & $\begin{array}{c}\mathbf{0 . 0 6 2} \\
(0.286) \\
433\end{array}$ & $\begin{array}{c}\mathbf{0 . 0 5 5} \\
(0.271) \\
1194\end{array}$ \\
\hline Workers displaced $1986^{3}$ & $\begin{array}{l}\text { First new job } 1986 \\
\text { Standard deviation } \\
\text { Observations } \\
\text { First new job } 1987 \\
\text { Standard deviation } \\
\text { Observations }\end{array}$ & $\begin{array}{c}\mathbf{- 0 . 0 1 5} \\
(0.252) \\
1,738 \\
\\
\mathbf{0 . 0 2 6} \\
(0.225) \\
1,345\end{array}$ & $\begin{array}{c}\mathbf{0 . 0 4 2} \\
(0.291) \\
253 \\
\\
\mathbf{0 . 0 3 2} \\
(0.275) \\
280\end{array}$ & $\begin{array}{c}\mathbf{- 0 . 0 0 8} \\
(0.258) \\
1,991 \\
\\
\mathbf{0 . 0 2 7} \\
(0.236) \\
1,634\end{array}$ \\
\hline
\end{tabular}

Note: Standard errors in parentheses. In the calculations only full-time employees before and after the change were included. From reported full-time employment those workers are deleted, who earn less than 12,000 DM per year. See text for details of the problem and further selections.

${ }^{1}$ For workers not displaced wage growth between the first job in 1986 and the first job in 1987 is calculated.

${ }^{2}$ For workers becoming unemployed or displaced wage growth between the pre-unemployment job in 1986 and the first job in 1987 is calculated.

${ }^{3}$ Wage growth between pre-unemployment job and the first full-time job after unemployment.

Source: Authors' calculations based on the IAB sample. 
Table A2 - Wage Growth Regressions for High and Low Wage Workers Excluding Recalls

\begin{tabular}{|c|c|c|c|c|c|}
\hline & All workers & 1. Quartile & $\begin{array}{l}\text { Sample } \\
\text { 2. Quartile }\end{array}$ & 3. Quartile & 4. Quartile \\
\hline Constant & $\begin{array}{c}0.3121 * * \\
(0.0052)\end{array}$ & $\begin{array}{c}0.4033 * * \\
(0.0129)\end{array}$ & $\begin{array}{c}0.0580 * * \\
(0.0087)\end{array}$ & $\begin{array}{c}0.0666 * * \\
(0.0102)\end{array}$ & $\begin{array}{c}0.0275 * * \\
(0.0102)\end{array}$ \\
\hline Displaced & $\begin{array}{c}-0.0364 * * \\
(0.0027)\end{array}$ & $\begin{array}{c}0.0187 * * \\
(0.0049)\end{array}$ & $\begin{array}{c}-0.1450 * * \\
(0.0049)\end{array}$ & $\begin{array}{c}-0.2013 * * \\
(0.0063)\end{array}$ & $\begin{array}{c}-0.3791 * * \\
(0.0077)\end{array}$ \\
\hline Age & $\begin{array}{c}-0.0118 * * \\
(0.0003)\end{array}$ & $\begin{array}{c}-0.0166^{* *} \\
(0.0007)\end{array}$ & $\begin{array}{l}-0.0005 \\
(0.0004)\end{array}$ & $\begin{array}{c}-0.0019 * * \\
(0.0005)\end{array}$ & $\begin{array}{l}-0.0009 * \\
(0.0004)\end{array}$ \\
\hline $\operatorname{Age}^{2} * 10^{-2}$ & $\begin{array}{c}0.0123 * * \\
(0.0003)\end{array}$ & $\begin{array}{c}0.0186 * * \\
(0.0008)\end{array}$ & $\begin{array}{c}0.0001 \\
(0.0005)\end{array}$ & $\begin{array}{l}0.0010^{*} \\
(0.0006)\end{array}$ & $\begin{array}{c}0.0005 \\
(0.0005)\end{array}$ \\
\hline Tech. training & $\begin{array}{l}-0.0005 \\
(0.0011)\end{array}$ & $\begin{array}{c}0.0072 * * \\
(0.0028)\end{array}$ & $\begin{array}{c}0.0019 \\
(0.0015)\end{array}$ & $\begin{array}{c}0.0008 \\
(0.0017)\end{array}$ & $\begin{array}{l}-0.0026 \\
(0.0020)\end{array}$ \\
\hline University & $\begin{array}{c}-0.0106 * * \\
(0.0017)\end{array}$ & $\begin{array}{c}0.0710 * * \\
(0.0144)\end{array}$ & $\begin{array}{c}0.0445 * * \\
(0.0059)\end{array}$ & $\begin{array}{c}0.0265^{* * *} \\
(0.0035)\end{array}$ & $\begin{array}{l}-0.0027 \\
(0.0021)\end{array}$ \\
\hline Blue collar with training & $\begin{array}{c}0.0052 * * \\
(0.0011)\end{array}$ & $\begin{array}{c}0.0146^{* * *} \\
(0.0029)\end{array}$ & $\begin{array}{c}0.0077 * * \\
(0.0015)\end{array}$ & $\begin{array}{c}0.0091 * * \\
(0.0018)\end{array}$ & $\begin{array}{c}0.0087 * * \\
(0.0032)\end{array}$ \\
\hline Foremen, master & $\begin{array}{c}0.0124 * * \\
(0.0020)\end{array}$ & $\begin{array}{c}0.0443 * * \\
(0.0100)\end{array}$ & $\begin{array}{c}0.0304 * * \\
(0.0040)\end{array}$ & $\begin{array}{c}0.0313^{* * *} \\
(0.0029)\end{array}$ & $\begin{array}{c}0.0305^{* *} \\
(0.0032)\end{array}$ \\
\hline White Collar & $\begin{array}{c}0.0119 * * \\
(0.0013)\end{array}$ & $\begin{array}{c}0.0318 * * \\
(0.0039)\end{array}$ & $\begin{array}{c}0.0192 * * \\
(0.0021)\end{array}$ & $\begin{array}{c}0.0284 * * \\
(0.0021)\end{array}$ & $\begin{array}{c}0.0285 * * \\
(0.0031)\end{array}$ \\
\hline Small firm & $\begin{array}{c}-0.0052 * * \\
(0.0011)\end{array}$ & $\begin{array}{c}-0.0124 * * \\
(0.0028)\end{array}$ & $\begin{array}{c}-0.0094 * * \\
(0.0018)\end{array}$ & $\begin{array}{l}-0.0033 \\
(0.0020)\end{array}$ & $\begin{array}{c}-0.0087 * * \\
(0.0016)\end{array}$ \\
\hline Large firm & $\begin{array}{c}0.0002 \\
(0.0009)\end{array}$ & $\begin{array}{c}0.0104 * * \\
(0.0025)\end{array}$ & $\begin{array}{c}0.0058 * * \\
(0.0013)\end{array}$ & $\begin{array}{c}0.0067 * * \\
(0.0014)\end{array}$ & $\begin{array}{c}0.0010 \\
(0.0010)\end{array}$ \\
\hline Previous tenure & $\begin{array}{c}-0.0055^{* *} \\
(0.0004)\end{array}$ & $\begin{array}{c}-0.0087 * * \\
(0.0011)\end{array}$ & $\begin{array}{c}-0.0025^{* *} \\
(0.0007)\end{array}$ & $\begin{array}{l}-0.0003 \\
(0.0007)\end{array}$ & $\begin{array}{l}-0.0009 \\
(0.0005)\end{array}$ \\
\hline $\begin{array}{l}\text { Previous tenure }^{2} * 10^{-2} \\
\text { Adj. } \mathbf{R}^{2}\end{array}$ & $\begin{array}{c}0.0323 * * \\
(0.0030) \\
0.07\end{array}$ & $\begin{array}{c}0.0468 * * \\
(0.0085) \\
0.10\end{array}$ & $\begin{array}{c}0.0122 * * \\
(0.0047) \\
0.09\end{array}$ & $\begin{array}{c}0.0018 \\
(0.0049) \\
0.11\end{array}$ & $\begin{array}{c}0.0073 * \\
(0.0035) \\
0.15\end{array}$ \\
\hline $\begin{array}{l}\text { Observations total } \\
\text { " classified as displaced }\end{array}$ & $\begin{array}{c}74,302 \\
1,356 \\
\end{array}$ & $\begin{array}{c}18,501 \\
939 \\
\end{array}$ & $\begin{array}{c}18,206 \\
230\end{array}$ & $\begin{array}{c}18,849 \\
140\end{array}$ & $\begin{array}{c}18,746 \\
47\end{array}$ \\
\hline
\end{tabular}

Note: Nine occupation dummies are included and not reported. Inclusion of higher digit dummies did not change the results. Reference group: no technical training, blue collar, technical occupation. $* *$ indicates significance at the $1 \%$-level and $*$ at the $5 \%$-level (onesided test). Source: Authors' calculations using the IAB sample. 
Table A3 - A Comparison of Two Probits

\begin{tabular}{|c|c|c|c|c|c|}
\hline & Probit 1 & Probit 2 & & Probit 1 & Probit 2 \\
\hline $\begin{array}{l}\text { Pseudo-R }{ }^{2} \\
\text { Observations }\end{array}$ & $\begin{array}{l}18.8 \\
959\end{array}$ & $\begin{array}{l}25.1 \\
3114\end{array}$ & & & \\
\hline Constant & $\begin{array}{l}-0.8794 * \\
(0.4139)\end{array}$ & $\begin{array}{c}-1.3161 * * \\
(0.2655)\end{array}$ & Construction & $\begin{array}{l}1.1274 * * \\
(0.2951)\end{array}$ & $\begin{array}{c}0.7596 * * \\
(0.1807)\end{array}$ \\
\hline Age & $\begin{array}{c}0.0018 \\
(0.0057)\end{array}$ & $\begin{array}{c}0.0059 \\
(0.0039)\end{array}$ & Trade & $\begin{array}{l}0.7468 * \\
(0.2999)\end{array}$ & $\begin{array}{r}0.4946 * * \\
(0.1832)\end{array}$ \\
\hline Age $*$ technical training & $\begin{array}{c}0.0155^{* *} \\
(0.0071)\end{array}$ & $\begin{array}{c}0.0129 * * \\
(0.0046)\end{array}$ & $\begin{array}{l}\text { Transport, } \\
\text { communication }\end{array}$ & $\begin{array}{l}1.0947 * * \\
(0.3460)\end{array}$ & $\begin{array}{c}0.3093 \\
(0.2129)\end{array}$ \\
\hline Age $*$ university & $\begin{array}{l}-0.0188 \\
(0.0267)\end{array}$ & $\begin{array}{c}0.0236 \\
(0.0143)\end{array}$ & Credit, insurance & $\begin{array}{l}-0.3219 \\
(0.6116)\end{array}$ & $\begin{array}{l}-0.3257 \\
(0.3481)\end{array}$ \\
\hline Foreigner & $\begin{array}{c}0.3027 * * \\
(0.1019)\end{array}$ & $\begin{array}{c}0.3746 * * \\
(0.0672)\end{array}$ & Other services & $\begin{array}{l}0.8150 * \\
(0.2856)\end{array}$ & $\begin{array}{r}0.4972 * * \\
(0.1758)\end{array}$ \\
\hline Technical training & $\begin{array}{c}-0.7219 * * \\
(0.2708)\end{array}$ & $\begin{array}{c}-0.6589 * * \\
(0.1733)\end{array}$ & Displacement 84 & $\begin{array}{l}-0.1803 \\
(0.1563)\end{array}$ & $\begin{array}{c}0.0854 \\
(0.1089)\end{array}$ \\
\hline University & $\begin{array}{c}0.3249 \\
(1.0013)\end{array}$ & $\begin{array}{l}-1.3766^{*} \\
(0.5430)\end{array}$ & Displacement 85 & $\begin{array}{l}-0.0451 \\
(0.1764)\end{array}$ & $\begin{array}{l}-0.0307 \\
(0.1152)\end{array}$ \\
\hline Blue collar with techn. training & $\begin{array}{l}-0.0218 \\
(0.1252)\end{array}$ & $\begin{array}{l}-0.1661 * \\
(0.0797)\end{array}$ & Displacement 86 & $\begin{array}{l}-0.1599 \\
(0.1817)\end{array}$ & $\begin{array}{l}-0.2673 * \\
(0.1178)\end{array}$ \\
\hline Foremen, master & $\begin{array}{c}0.1352 \\
(0.4757)\end{array}$ & $\begin{array}{l}-0.4684 \\
(0.2959)\end{array}$ & Displacement 87 & $\begin{array}{l}-0.1985 \\
(0.1773)\end{array}$ & $\begin{array}{l}-0.2153 \\
(0.1203)\end{array}$ \\
\hline White collar & $\begin{array}{l}-0.1932 \\
(0.1319)\end{array}$ & $\begin{array}{c}-0.3307 * * \\
(0.0843)\end{array}$ & Displacement 88 & $\begin{array}{l}-0.1178 \\
(0.2025)\end{array}$ & $\begin{array}{r}-0.2468 * \\
(0.1252)\end{array}$ \\
\hline Job duration 0-3 years & $\begin{array}{c}0.2212 \\
(0.1457)\end{array}$ & $\begin{array}{c}0.3967 * * \\
(0.0946)\end{array}$ & Displacement 89 & $\begin{array}{l}-0.3512^{+} \\
(0.1902)\end{array}$ & $\begin{array}{c}-0.4910 * * \\
(0.1205)\end{array}$ \\
\hline Job duration 3-10 years & $\begin{array}{c}0.2106 \\
(0.1352)\end{array}$ & $\begin{array}{c}0.2512 * * \\
(0.0890)\end{array}$ & Displacement 90 & $\begin{array}{c}-0.8366 * * \\
(0.1917)\end{array}$ & $\begin{array}{c}-0.6555 * * \\
(0.1228)\end{array}$ \\
\hline Small firm & $\begin{array}{c}0.1685 \\
(0.1104)\end{array}$ & $\begin{array}{l}0.1618 * \\
(0.0712)\end{array}$ & Displacement 91 & $\begin{array}{c}-0.7166^{* * *} \\
(0.1811)\end{array}$ & $\begin{array}{c}-0.6038 * * * \\
(0.1196)\end{array}$ \\
\hline Large firm & $\begin{array}{c}-0.0142 \\
(0.1085)\end{array}$ & $\begin{array}{c}-0.2118 * * \\
(0.0693)\end{array}$ & Displacement 92 & $\begin{array}{c}-0.5146 * * \\
(0.1831)\end{array}$ & $\begin{array}{c}-0.4231 * * \\
(0.1202)\end{array}$ \\
\hline Manufacturing & $\begin{array}{c}0.7837 * * \\
(0.2735)\end{array}$ & $\begin{array}{c}0.5106 * * \\
(0.1663)\end{array}$ & & & \\
\hline
\end{tabular}

Note: Dependent variable equals one if the mover has been made redundant and zero otherwise. Probit 1: only movers with unemployment experience. Probit 2: all movers. Further selections: see text. ** indicates significance at the $1 \%$ level, $*$ at the $5 \%$ level and ${ }^{+}$at the $10 \%$ level. The reference groups are blue collar workers without technical training in the state or energy/mining sector with more than 10 years of tenure displaced in 1993 from a medium sized firm. Source: Authors' calculations based on the GSOEP. 
Table A4 - Two-Year Growth in Hourly Wages in the GSOEP

\begin{tabular}{|c|c|c|c|}
\hline & Observations & Mean wage growth & Standard Deviation \\
\hline Stable full-time workers & 15121 & 0.0370 & 0.3912 \\
\hline All displaced workers & 125 & 0.0002 & 0.3337 \\
\hline All movers & 1058 & 0.0701 & 0.4312 \\
\hline $\begin{array}{l}\text { Displaced workers with } \\
\text { unemployment experience }\end{array}$ & 56 & 0.0083 & 0.3239 \\
\hline $\begin{array}{l}\text { Predicted displaced workers - } \\
\text { Probit } 1\end{array}$ & 39 & -0.1166 & 0.5168 \\
\hline $\begin{array}{l}\text { Predicted displaced workers - } \\
\text { Probit } 2\end{array}$ & 225 & 0.0277 & 0.5280 \\
\hline
\end{tabular}

Note: Pooled two year samples between 1985 and 1994. Probit 1 is based on workers who experience an unemployment spell. Probit 2 is based on all movers whether they experience unemployment or not. Source: Authors' calculations using the GSOEP. See text for details.

Table A5 - Long Run Wage Losses of Male Workers

\begin{tabular}{|c|c|c|c|c|c|}
\hline & \multicolumn{5}{|c|}{ Sample } \\
\hline & All workers & 1. Quartile & 2. Quartile & 3. Quartile & 4. Quartile \\
\hline Excluding recalls & & & & & \\
\hline 1986-1987 & $\begin{array}{c}-0.0364 * * \\
(0.0027)\end{array}$ & $\begin{array}{c}0.0187 * * \\
(0.0049)\end{array}$ & $\begin{array}{c}-0.1450 * * \\
(0.0049)\end{array}$ & $\begin{array}{c}-0.2013 * * \\
(0.0063)\end{array}$ & $\begin{array}{c}-0.3791 * * \\
(0.0077)\end{array}$ \\
\hline 1986-1988 & $\begin{array}{c}-0.0367 * * \\
(0.0029)\end{array}$ & $\begin{array}{c}0.0142 * * \\
(0.0142)\end{array}$ & $\begin{array}{c}-0.1317 * * \\
(0.0057)\end{array}$ & $\begin{array}{c}-0.2067 * * \\
(0.0073)\end{array}$ & $\begin{array}{c}-0.3483 * * \\
(0.0082)\end{array}$ \\
\hline 1986-1989 & $\begin{array}{c}-0.0354 * * \\
(0.0031)\end{array}$ & $\begin{array}{c}0.0201 * * \\
(0.0201)\end{array}$ & $\begin{array}{c}-0.1308 * * \\
(0.0061)\end{array}$ & $\begin{array}{c}-0.2246 * * \\
(0.0075)\end{array}$ & $\begin{array}{c}-0.3802 * * \\
(0.0086)\end{array}$ \\
\hline 1986-1990 & $\begin{array}{c}-0.0216^{* *} * \\
(0.0033)\end{array}$ & $\begin{array}{c}0.0274 * * \\
(0.0057)\end{array}$ & $\begin{array}{c}-0.1007 * * \\
(0 . .0067)\end{array}$ & $\begin{array}{c}-0.2121 * * \\
(0.0081)\end{array}$ & $\begin{array}{c}-0.3444 * * \\
(0.0091)\end{array}$ \\
\hline Including recalls & & & & & \\
\hline 1986-1987 & $\begin{array}{c}-0.0264 * * \\
(0.0020)\end{array}$ & $\begin{array}{c}0.0184 * * \\
(0.0039)\end{array}$ & $\begin{array}{c}-0.0674 * * \\
(0.0032)\end{array}$ & $\begin{array}{c}-0.1119 * * \\
(0.0040)\end{array}$ & $\begin{array}{c}-0.2033 * * \\
(0.0051)\end{array}$ \\
\hline 1986-1988 & $\begin{array}{c}-0.0291 * * \\
(0.0023)\end{array}$ & $\begin{array}{c}0.0184 * * \\
(0.0044)\end{array}$ & $\begin{array}{c}-0.0769 * * \\
(0.0040)\end{array}$ & $\begin{array}{c}-0.1431 * * \\
(0.0050)\end{array}$ & $\begin{array}{c}-0.1991 * * \\
(0.0059)\end{array}$ \\
\hline 1986-1989 & $\begin{array}{c}-0.0382 * * \\
(0.0025)\end{array}$ & $\begin{array}{c}0.0204 * * \\
(0.0204)\end{array}$ & $\begin{array}{c}-0.0940 * * \\
(0.0046)\end{array}$ & $\begin{array}{c}-0.1822 * * \\
(0.0054)\end{array}$ & $\begin{array}{c}-0.2571 * * \\
(0.0065)\end{array}$ \\
\hline 1986-1990 & $\begin{array}{c}-0.0237 * * \\
(0.0028)\end{array}$ & $\begin{array}{c}0.0281 * * \\
(0.0050)\end{array}$ & $\begin{array}{c}-0.0771 * * \\
(0.0052)\end{array}$ & $\begin{array}{c}-0.1596 * * \\
(0.0062)\end{array}$ & $\begin{array}{c}-0.2403 * * \\
(0.0070)\end{array}$ \\
\hline
\end{tabular}

Note: Standard errors in parentheses. $* *$ indicates significance at the $1 \%$-level and * at the 5\%-level (one-sided test). Included are workers displaced in 1986 and employed in the year for which wage growth is calculated. The control group consists of workers who work 365 days each year during the time span of the respective wage growth regression. Source: Authors' calculations based on the IAB-sample. 